THE IMPACT OF GREEN INNOVATION ON ENERGY INTENSITY: AN EMPIRICAL ANALYSIS FOR 14 INDUSTRIAL SECTORS IN OECD COUNTRIES

Jules-Daniel WURLOD, Joëlle NOAILLY 


\title{
The Impact of Green Innovation on Energy Intensity:
}

\section{An Empirical Analysis for 14 Industrial Sectors in OECD}

\section{Countries}

\author{
Jules-Daniel Wurlod* Joëlle Noailly
}

This version: June 2016

\begin{abstract}
This paper analyses the impact of green innovation on energy intensity in a set of 14 industrial sectors in 17 OECD countries over the 1975-2005 period. We create a stock of green patents for each industrial sector and estimate a translog cost function to measure the impact of green innovation on energy intensity, next to other factors such as input substitution and autonomous technical change. We find that green innovation has contributed to the decline in energy intensity in the majority of sectors: the median elasticity of energy intensity with respect to green patenting is estimated at -0.03 in our sample. Hence, a $1 \%$ increase in green patenting activities in a given sector is associated with a $0.03 \%$ decline in energy intensity. The magnitude of the effect is larger in energy-intensive sectors and in more recent years. We also find that the impact of an additional green patent on energy intensity is larger than an average non-green patent. Our results are robust to alternative definitions of green patents.
\end{abstract}

Keywords: Energy intensity, Green innovation; Patents; Technology; Cost function

JEL Codes: Q41; O33

${ }^{*}$ CIES, Graduate Institute of International and Development Studies, Geneva, Switzerland. E-mail: julesdaniel.wurlod@graduateinstitute.ch. Tel: +41/79.664.53.27. Address: Department of Economics and Centre for International Environmental Studies, Graduate Institute of International and Development Studies, P.O. Box 36, 1211 Geneva 21, Switzerland.

${ }^{\dagger}$ Corresponding author, CIES, Graduate Institute of International and Development Studies, Geneva, Switzerland. E-mail: joelle.noailly@graduateinstitute.ch. Tel: +41/22.908.62.22. Address: Department of Economics and Centre for International Environmental Studies, Graduate Institute of International and Development Studies, P.O. Box 36, 1211 Geneva 21, Switzerland.

${ }^{\ddagger}$ Jules-Daniel Wurlod acknowledges funding from the Swiss Federal Office of Energy. Joelle Noailly acknowledges funding from the People Programme Marie Curie Actions of the European Union (FP7-PEOPLE-2012-IEF) under grant agreement number 329071. We are very thankful to Travis Lybbert (UC Davis) for providing us the most complete and recent version of the 'algorithmic links with probabilities' database. We thank Mathieu Glachant, Antoine Dechezlepretre, Elena Verdolini, Valentina Bosetti, Jan Witajewski, as well as participants at seminars at the YSEM Conference at KOF Zurich, the Sinergia workshops, the 2015 IAEE Conference and the 2015 EAERE Conference for useful comments. 


\section{Introduction}

Reducing the energy intensity ${ }^{1}$ of production processes is a core objective of climate policies since it is an important mean to reduce carbon emissions. According to estimates of the International Energy Agency, 31\% of emissions reductions necessary to halve emissions by 2050 compared to 2009 levels can be achieved through this lever (IEA, 2012). In addition, decreases in energy intensity contribute to the competitiveness of industries facing higher energy prices, which makes energy efficiency a 'win-win' objective for policymakers and the private sector (Porter and Van der Linde, 1995). Finally, the decoupling of economic growth from energy use may also contribute to improve energy security and the resilience of economies depending on energy imports.

Over the last decades, industrialized countries have witnessed a significant decrease in the energy intensity of their economies. As shown in Figure 1, energy intensity, i.e. the quantity of energy used per unit of production value, declined on average by a factor of 4 over 1970-2005. According to recent studies (e.g. Mulder and de Groot, 2012; Voigt et al., 2014), this decline is mainly explained by improvements within sectors, rather than across sectors. In other words, the decrease in energy intensity at the aggregate level is not explained by a composition effect, i.e. a shift to cleaner sectors in the economy, but rather the result of a more efficient use of energy within industries. There are two main within industry sources of improvements, namely input substitution - whenever firms substitute energy by using more labour or capital for instance, or technological innovation - whenever firms save on energy by using new energy-efficient production techniques. As an illustration, Figure 1 shows that the stock of green technologies, as proxied by the cumulative number of green patenting activities over time in our set of 17 OECD countries ${ }^{2}$, has been steadily increasing over time since the 1980s.

Since an increase in energy prices can trigger both a substitution of inputs away from energy and innovation in green technologies, Figure 1 also plots the evolution of the prices of energy over time. While energy intensity seems to be negatively correlated with energy prices until mid-1980s, the relationship is less clear for the second part of the period. The objective of the current study is to clarify empirically the role of green technologies for the decline in energy intensity for a set

\footnotetext{
${ }^{1}$ Energy efficiency is defined as a technical measure, i.e. a ratio of input and output, whereas energy intensity refers to the quantity of energy used over the value of production.

${ }^{2}$ The precise definition of the stock of green patents is given in Section 3.
} 
Figure 1: Energy intensity, energy prices and green patent stocks - OECD average

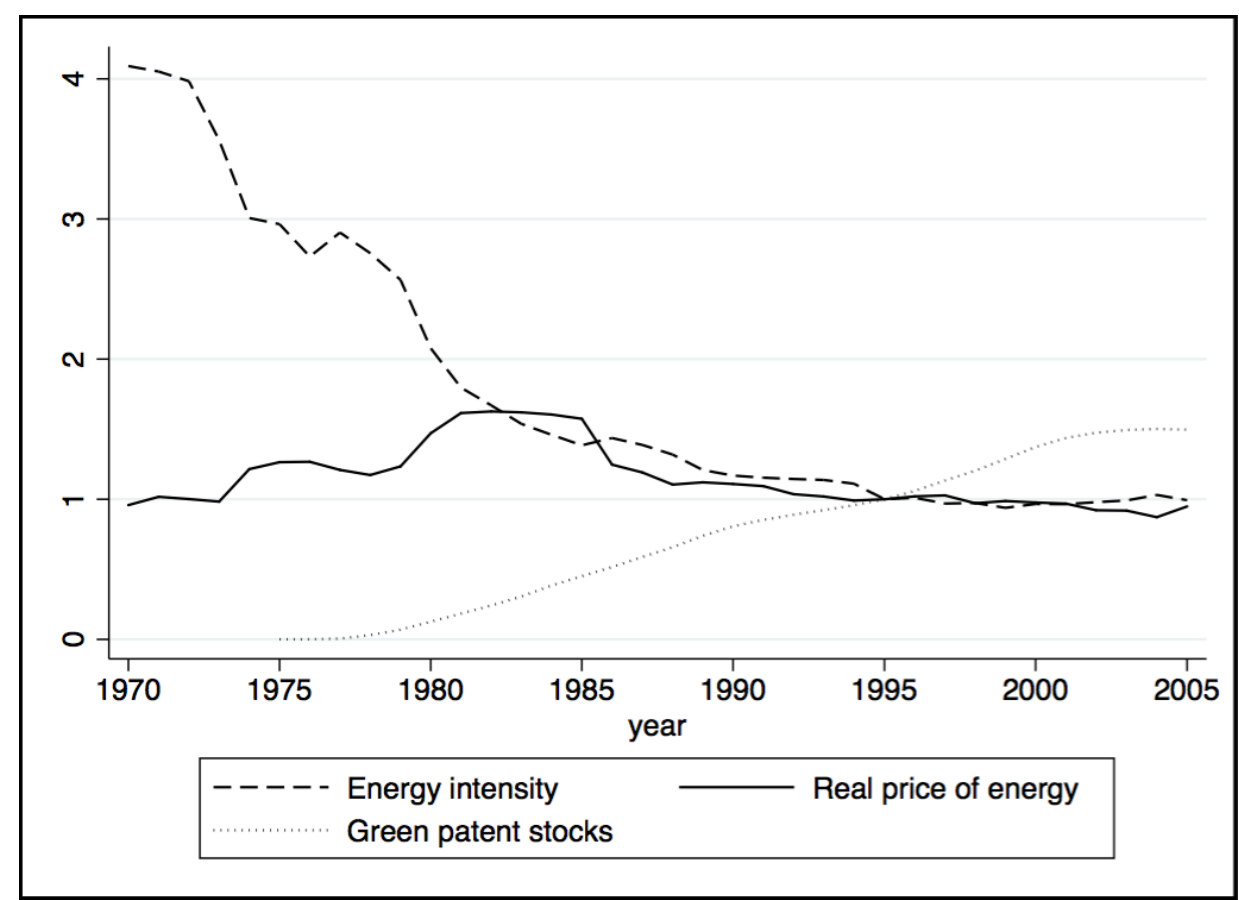

Notes: All data have been normalized so that $1995=1$ and are averaged across sectors. Energy intensity is the ratio of an index of quantity of energy to value of output. Green patent stock is the average of the sector-specific stock of energy efficient patents. Real prices of energy are indexes of constant 1995 USD.

of 14 industrial sectors in 17 OECD countries over the 1975-2005 period. Green technologies are defined as technologies impacting energy usage, such as combustion processes or heat exchange apparatuses. Using the OECD Triadic Patent Families database, we identify green patenting activities using International Patent Classification (IPC) codes (Johnstone et al., 2010; Popp, 2001) and match patents to industrial sectors by applying a recently developed concordance table (Lybbert and Zolas, 2014). This allows us to compute the stock of relevant green innovation for each industrial sector in our set of OECD countries. Using production data at the industry level from the EU-KLEMS database, we estimate a translog production function following the (widely-used) framework developed by Berndt and Wood (1975) (see for example Haller and Hyland, 2014; Kim and Heo, 2013; Arnberg and Bjorner, 2007) to measure the impact of green patents on energy intensity per sector. We find that an increase in green patenting activities is associated with a reduction in energy intensity in most of the sectors in our sample, with a median elasticity of -0.03 . Hence, a $1 \%$ increase in green patenting activities in a given sector is associated with a $0.03 \%$ decline in 
energy intensity at the median. We also find that the magnitude of the effect for green patents is larger in energy-intensive sectors and also larger than an average non-green patent.

Our study is related to an extensive literature which has used input demand functions to identify substitution patterns, in particular between energy and capital, since the 1970's (Binswanger, 1974; Berndt and Wood, 1975; Apostolakis, 1990). This literature has mainly focused on the role of energy prices on the demand for energy and capital inputs. Instead, the impact of technology has been neglected as the latter is often simply modelled as a time trend in the demand equations (for example in Jorgenson and Fraumeni, 1981; Welsch and Ochsen, 2005; Ma et al., 2008). This presents important drawbacks. First, it does not allow to cater to the induced innovation literature, which states that when energy prices are high, firms will tend to innovate in order to develop energy-saving technologies (Hicks, 1932; Ahmad, 1966; Jaffe and Palmer, 1997; Newell et al., 1999; Acemoglu, 2002; Popp, 2002). Second, the use of a time trend allows to observe only aggregate technical change without pinning down the specific effect of energy-saving technologies. The major reasons for this simplification in the energy input demand functions were first the absence of global datasets on innovation, and second the need for concordance tables to relate technologies to their potential sector of use to bridge the gap between patents and industrial sectors.

Some recent papers have circumvented the lack of specific measure of technology by using past energy prices as a proxy for biased technical change (Sue Wing, 2008; Mulder et al., 2014). Sue Wing (2008), for example, finds that within-sector gains in energy intensity in the U.S. occur through price-induced substitution of variable inputs, adjustments in quasi-fixed inputs, and, to a limited extent, through price-induced innovation. However, the use of past energy prices as a proxy for biased technical change requires the ex-ante assumption that energy prices are indeed an incentive to innovate. In contrast, Popp (2001) presents an unique study on the role of energyefficient innovation on sectoral energy intensity where technology is measured using patent data. The author uses a concordance table based on Canadian industries, the Yale Concordance Table, to match technologies to their potential sectors of use, and finds an estimate of -0.06 for the short run elasticity between green technology and energy intensity averaged across all sectors. Overall, his results suggest that price-induced input substitution and induced innovation decreased energy consumption by a factor of two-thirds and one-third respectively. By contrast to this analysis, which was limited to the US, our study brings novel insights on the impact of green innovation on 
energy intensity for a large set of OECD countries. This helps to uncover whether the US results can be generalized more broadly. Moreover, his study is limited to the 1972-1991 period, leaving out an important time period in terms of green innovation. Our analysis is original as it covers three decades of data up to 2005.

The remainder of this paper is structured as follows. Section 2 describes our empirical methodology. Section 3 provides a discussion of our data sources as well as some descriptive statistics. Section 4 presents the estimation results. Section 5 concludes.

\section{Theoretical Framework}

There is a large body of literature estimating energy demand using a cost function approach following the pioneering work of Berndt and Wood (1975). ${ }^{3}$ We consider an industry's production function:

$$
Y=f(K, L, E, M, T)
$$

where $f(\cdot)$ represents an industry's technology that produces output $Y$ using the four input factors: capital $K$, labor $L$, materials $M$ and energy $E$, and $T$ the level of technology. We transform Equation (1) into a cost function by using the duality theorem between production and cost functions (Shephard, 1953): ${ }^{4}$

$$
C=g\left(P_{K}, P_{L}, P_{M}, P_{E}, Y, T\right)
$$

where $C$ is the minimum cost required to produce $Y$ and $P_{i}$ is the $i$-th input price. This allows to circumvent the issue of estimating production functions with endogenous choice of inputs (Binswanger, 1974). As the level of inputs is a choice variable for firms, estimating econometrically a production function potentially violates the assumption of strict exogeneity of regressors, as there could be numerous factors affecting simultaneously the output level and the choice of inputs. By using input prices in a cost function framework, this particular problem is most likely avoided, as prices can be considered exogenous provided that sectors are small. In addition, for the purpose

\footnotetext{
${ }^{3}$ Recent studies include Welsch and Ochsen (2005); Arnberg and Bjorner (2007); Ma et al. (2008); Kim and Heo (2013); Haller and Hyland (2014).

${ }^{4}$ Under the duality theorem, if the production function is twice differentiable, then there is a corresponding cost function that is also twice differentiable.
} 
of estimation, a flexible functional form imposing no a priori restrictions on the elasticities of substitution is preferred to estimate $g(\cdot)$. We thus employ a translog cost function, which makes no restrictive assumptions on the estimated substitution elasticities and on the optimal path of input factor adjustments induced by price changes (Christensen et al., 1973), expressed as: 5

$$
\begin{aligned}
\ln C & =\beta_{0}+\sum_{i} \beta_{i} \ln P_{i}+\beta_{Y} \ln Y+\beta_{T} \ln T \\
& +\frac{1}{2} \beta_{Y Y}(\ln Y)^{2}+\frac{1}{2} \beta_{T T}(\ln T)^{2}+\frac{1}{2} \sum_{i} \sum_{j} \beta_{i j} \ln P_{i} \ln P_{j} \\
& +\sum_{i} \beta_{i Y} \ln Y \ln P_{i}+\sum_{i} \beta_{i T} \ln T \ln P_{i}
\end{aligned}
$$

with $i, j=K, L, M, E$. Slutsky symmetry condition is imposed by setting $\beta_{i j}=\beta_{j i}$. Because of the collinearity problem, an estimation of the first derivatives of (2) is preferred to a direct estimation of the cost function. Cost minimization w.r.t. input prices implies the following:

$$
\frac{\partial \ln C}{\partial \ln P_{i}}=\beta_{i}+\frac{1}{2} 2 \beta_{i K} \ln P_{K}+\frac{1}{2} 2 \beta_{i L} \ln P_{L}+\frac{1}{2} 2 \beta_{i E} \ln P_{E}+\beta_{i Y} \ln Y+\beta_{i T} \ln T
$$

Under Shephard's lemma, assuming cost minimization, the demand functions for input $i$ are equal to the derivative of expenditures with respect to price (i.e the cost shares for each input). Equation (3) equals the energy cost share:

$$
\frac{\partial \ln C}{\partial \ln P_{i}}=\frac{\partial C}{\partial P_{i}} \frac{P_{i}}{C}=Q_{i} \frac{P_{i}}{C}=\frac{P_{i} Q_{i}}{C}=s_{i}
$$

where $s_{i}$ is the cost share of the $i$-th input. Hence, the cost share for each input is defined as:

$$
s_{i}=\beta_{i}+\sum_{j} \beta_{i j} \ln P_{j}+\beta_{i Y} \ln Y+\beta_{i T} \ln T
$$

The inclusion of $\beta_{i Y}$ measures potential scale effects in production, or whether the size of the sector affects the cost share of inputs (for example if an increase in the output of the sector shifts the production function towards, say, more capital). The coefficient $\beta_{i T}$ measures shifts due to technical change. To ensure homogeneity of degree one in prices (a doubling of all prices results

\footnotetext{
${ }^{5}$ See Thompson (2006) for a discussion of the specification of the translog cost function.
} 
in a doubling of total costs), the following restrictions are imposed:

$$
\sum_{i} \beta_{i}=1 \quad \text { and } \quad \sum_{i} \beta_{i j}=\sum_{i} \beta_{i Y}=\sum_{i} \beta_{i T}=0
$$

Since cost shares sum up to unity, the disturbance terms sum up to one, making the covariance matrix singular. The estimation procedure involves dropping one of the equations from the equation system and normalizing all input prices. ${ }^{6}$ Since the objective of our paper is to measure the contribution of green technologies in particular, we decompose the technology variable between green technology $(\mathrm{G})$ and autonomous technical change captured by a time trend $t: 7,8$

$$
s_{i}=\beta_{i}+\beta_{i L} \ln \frac{P_{L}}{P_{M}}+\beta_{i E} \ln \frac{P_{E}}{P_{M}}+\beta_{i K} \ln \frac{P_{K t}}{P_{M}}+\beta_{i Y} \ln Y+\beta_{i G} \ln G+\beta_{i t} t+\varepsilon_{i}
$$

for $i=K, L, E$ with cross-equation symmetry imposed. We estimate this equation using iterated three-stage least squares (Berndt, 1991) such that results are not sensitive to the choice of the omitted equation. We take advantage of our panel data structure to estimate the system of Equations (6) sector-by-sector while controlling for unobserved heterogeneity at the country level.

We measure the impact of green technology by computing the elasticity of energy intensity with respect to green technology. To obtain this elasticity, the first step is to derive energy intensity from the cost share functions as defined in Equation (6). Using the zero profit condition stating that $T C=p_{Y} Y$ and substituting into the definition of $s_{E}$ as in Welsch and Ochsen (2005), we are able to recover energy intensity $E / Y$. We simply multiply $s_{E}$ by $\frac{P_{Y}}{P_{E}}$ :

$$
s_{E}=\frac{P_{E} E}{T C}=\frac{P_{E} E}{P_{Y} Y} ; \quad \frac{E}{Y}=\frac{P_{Y}}{P_{E}} s_{E}
$$

Using hats to denote estimated parameters, the elasticity of energy intensity w.r.t. green technology is: ${ }^{9}$

\footnotetext{
${ }^{6}$ The choice of numeraire should not affect the estimated elasticities. Here, following Welsch and Ochsen (2005), we use material input as numeraire.

${ }^{7}$ Obviously, different empirical specifications are possible, each answering different research questions related to innovation. For instance, one could focus on overall technical change and thus use total patents, or on directed technical change and use the share of green patents. In this paper we are primarily interested in measuring the impact of green technologies. We also provide estimates of the impact of general, non-green technologies in a robustness check.

${ }^{8}$ This framework measures the input bias of technological change (a potential shift in the isoquant structure or slope), and thereby ignore Hicks neutral technological change affecting all inputs simultaneously. Empirical studies testing for evidence of neutrality of technological change usually reject it (Hesse and Tarkka, 1986; Hunt, 1986).

${ }^{9}$ Derivation can be found in Appendix A.
} 


$$
\hat{\epsilon}_{E, G}=\frac{\partial \ln (E / Y)}{\partial \ln G}=\frac{\hat{\beta}_{E G}}{\hat{s}_{E}}
$$

with $\hat{\beta}_{E G}$ and $\hat{s}_{E}$ the estimated coefficients on green technological change in the energy demand equation and the mean predicted cost share of energy.

\section{Data and Descriptive Statistics}

\subsection{Patent data}

Technological innovation is measured using patent counts. Besides being readily available, patents present the advantage of being a good indicator of innovative activity and tend to be highly correlated with a large number of alternative measures of innovation (see Acs and Audretsch, 1989; Comanor and Scherer, 1969; Griliches, 1990; Hagedoorn and Cloodt, 2003; Popp, 2005). We extract patent data for 17 countries from the OECD Triadic Patent Families (TPF) database (Dernis and Khan, 2004), over the 1975-2005 period. ${ }^{10}$ Triadic patents families are patents filed at the European, Japanese and US patent offices (respectively, EPO, JPO and USPTO) to protect the same invention. ${ }^{11}$ These technologies tend to be of much higher economic value than patents filed only at a single national authority, as firms would only be willing to bear the substantial costs involved with filing a patent at the EPO, JPO and USPTO, if they expect their invention to be of high commercial value (Nesta et al., 2014). This quality hurdle thus removes low-value inventions, reducing the variance in patent quality (Johnstone et al., 2010), identified as one of the main challenges of methodologies using simple patent counts (Griliches, 1990; Popp, 2001). The use of triadic patents also has the advantage to reduce the home bias (Griliches, 1990): applicants tend to apply for patent protection in their home country more than in other countries, overestimating the stock of patent of domestic applicants compared to foreign applicants when relying on data from a single patent office.

Following Jaffe et al. (1993) (see also the OECD patent manual, 2009), we allocate patents to countries using the address of the inventor. When a patent is invented by multiple inventors

\footnotetext{
${ }^{10}$ We consider the following countries: Austria, Belgium, Germany, Denmark, Spain, Finland, France, Great Britain, Italy, Japan, South Korea, Luxembourg, the Netherlands, Portugal, Sweden, Slovenia and the United States.

${ }^{11}$ For a typology of patent families, please refer to Dernis and Khan (2004) or Martinez (2010).
} 
located in different countries, we disaggregate them using fractional counts. We count patents per priority year, which is the date closest to the date of invention (see OECD, 2009, chapter 4).

\subsubsection{Identification of green patents by sector}

Our identification of the relevant green technologies uses the following strategy. In a first step, we start from the broadest possible list of green patented technologies - identified using International Patent Classification (IPC) codes. We use the extensive list of climate change mitigation technologies provided in Dechezlepretre et al. (2011) and complement it with the list of technologies more specifically relevant to energy-efficiency selected by Popp (2001). This gives us a list of 1,529 technology classes defined at the 6-digit IPC code. ${ }^{12}$ We use fractional counts for patents with several IPC codes. If a given patent specifies two technological fields, among them only one relevant for our analysis, 0.5 patent will be allocated to the prevailing country/year.

In a second step, we relate patents (coded in IPC) to their sectors of use (coded in ISIC or NACE), i.e. sectors in which these specific technologies are used in the production process. We rely on the recently released ALP ('Algorithmic Links with Probabilities') concordance table developed by Lybbert and Zolas (2014) together with the World Intellectual Property Organization (WIPO). This table makes it possible to link patents and economic data through technologyindustry associations. The authors use a text analysis software and keyword extraction programs to develop a probability distribution of possible industries with which a patent in a given technology field may be associated. For each patent, the table provides us with a list of economic sectors with a corresponding probability. ${ }^{13}$ In essence, these probability weights blend two types of links, namely usage and production of technologies (Lybbert and Zolas, 2014), reflecting the fact that technologies are allocated to industries either because they are used therein, or because the technology was developed by this industry. Ideally, our study would include only usage links. Yet, in their robustness analysis, Lybbert and Zolas (2014) find that there are only negligible differences between their estimated weights and the weights of other methodologies distinguishing

\footnotetext{
${ }^{12}$ The complete list of IPC codes can be provided upon request.

${ }^{13}$ Several modifications are made. First, because the concordance table developed by Lybbert and Zolas (2014) provide the sectors of use in ISIC 3.1 code, while our production data is provided in NACE rev.1, we use the concordance table from the United Nations Statistical Division to match sector codes (available at http:/ / unstats.un.org/unsd/cr/registry). Second, the output from the concordance table is provided in disaggregated NACE sectors $(1.11,1.12,1.13)$, while EU-KLEMS data is provided only in aggregated NACE (11). We thus simply add up the weights provided by the table for each of the aggregated NACE codes.
} 
between sector of use (usage) and industry of manufacture (production) (Lybbert and Zolas, 2014, p. 537). While the concordance table allows us to screen out green patents that are not being used in a given sector (e.g. solar technologies in the pulp-and-paper industry), we may be concerned about two remaining sources of measurement errors.

First, some patents identified as green could still be unrelated to energy consumption. For instance, end-of-pipe technologies, such as a pollution filter, may be identified as green patents for their pollution reduction effect, but are not likely to affect energy usage. This could result in an overestimation of the stock of patents compared to energy-efficient patents narrowly defined, thereby adding statistical noise and blurring our estimations. To check the relevance of this concern, we identified the sectors of use provided by the concordance matrix for renewable energy patents (wind, solar, hydro, marine and biomass) for which the energy-saving characteristics are the least obvious. Most of these technologies are allocated to the sector NACE 40 (Generation of electricity), as expected, and fall in other industrial sectors with a small probability. As an illustration, wind technologies are allocated with a 0.72 probability to electricity production, but also with a probability of 0.125 to NACE 29 (Machinery nec). Nonetheless, we choose to keep these patents in our baseline specification for transparency, in order to avoid arbitrary choices in technologies where indirect, less obvious energy use reduction could still exist. An overestimation of the stock of patents could increase the risk finding no statistically significant coefficient when the true parameter value in fact is significant, but does not prevent us to make conclusive arguments on parameters found statistically significant as long as these are uncorrelated with the error term. We provide a robustness specification in Section 4.1 including only patents specifically defined as energy-reduction technologies, as defined in Popp (2001).

An additional measurement error can arise as, although we use the most comprehensive list of green IPC codes available, in theory there might exist additional energy-efficient technologies excluded from our selection. In this case, we might be underestimating the stock of green knowledge, implying that our estimates may be only a lower bound. We provide another robustness specification in Section 4.1 that includes the stock of non-green patents as an additional regressor, such as to limit the risk of misidentification of green patents.

Table 1 presents the list of IPC classifications related to each sector and the associated concordance weight from Lybbert and Zolas (2014), for a selection of industries: NACE sectors 21 (Pulp 
and Paper), 24 (Chemicals), 27 (Basic metals) and 28 (Fabricated Metals). ${ }^{14}$ For example, the probability weight between the green IPC class D21C 11 (Regeneration of pulp liquors) and the NACE sector 21 t22 (Pulp \& Paper) is $85 \%$. In words, this technology has a probability of $85 \%$ of being used in this sector. We then count the number of patents allocated to each sector of use weighted by the corresponding probabilities. For example, if there are 10 patents in this IPC classification in a given year (each with only a single inventor and a single IPC code), a flow of 8.5 patents will be allocated to this industrial sector. Note that weights for each technology class sum up to one, such that the total count of patents remains unchanged after being split between sectors of use.

\footnotetext{
${ }^{14}$ Note that the concordance weights presented in Table 1 for illustration purposes correspond to aggregated technology classes (6-digits). By contrast, green patents are selected upstream at a finer level (8-digits). This explains why some IPC classes in Table 1 seem only loosely related to energy consumption.
} 


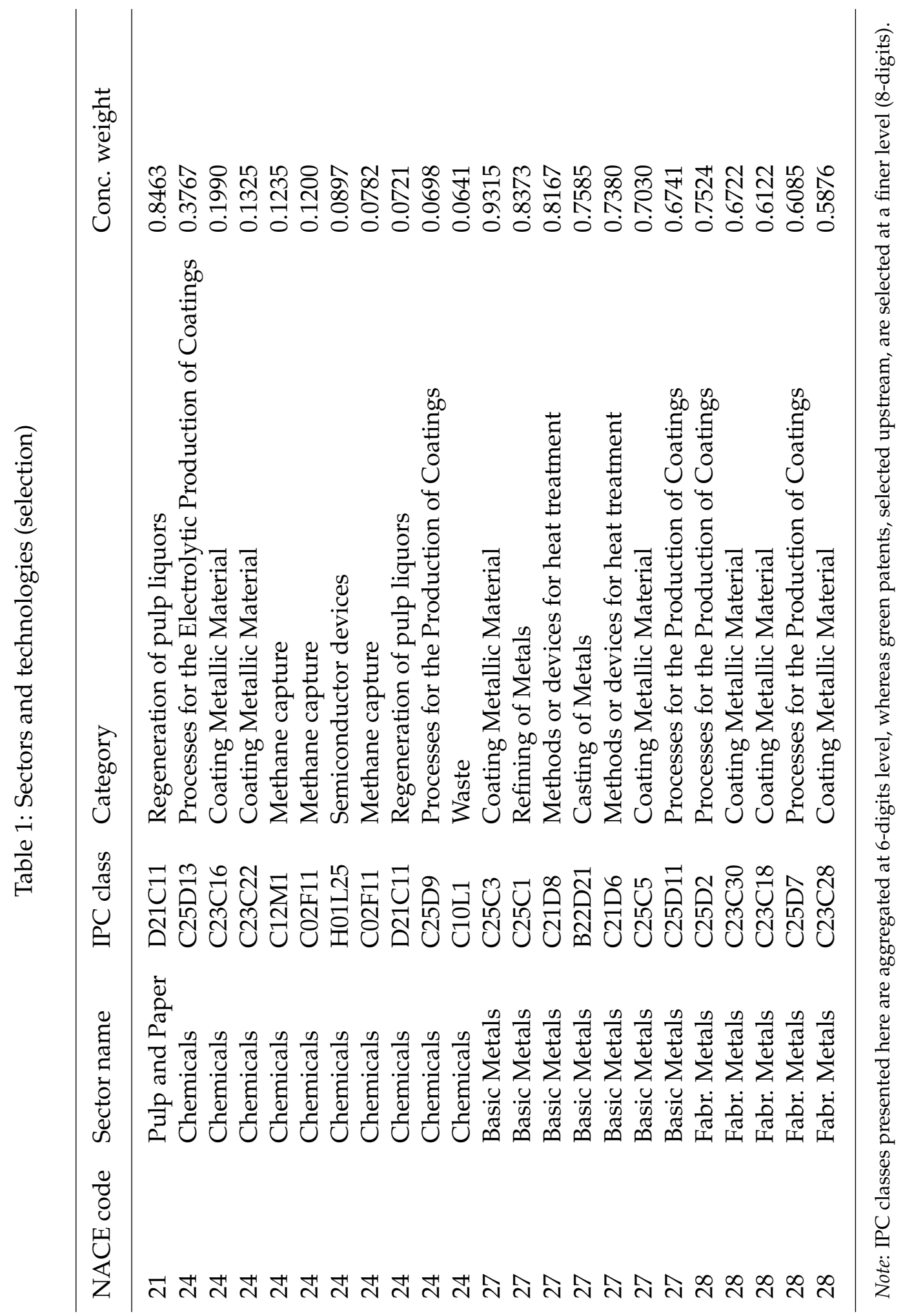


Figure 2: Green patent stocks - sample average

(a) By sector

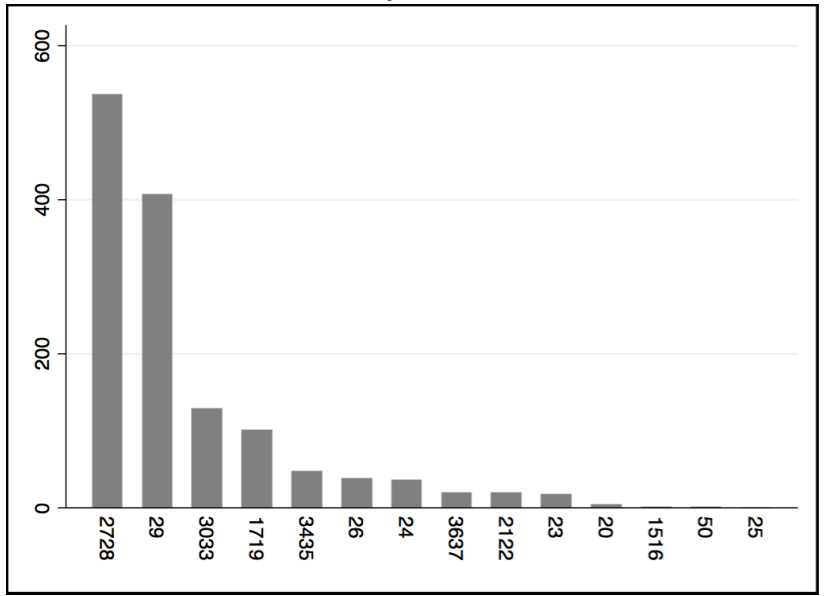

(b) By country

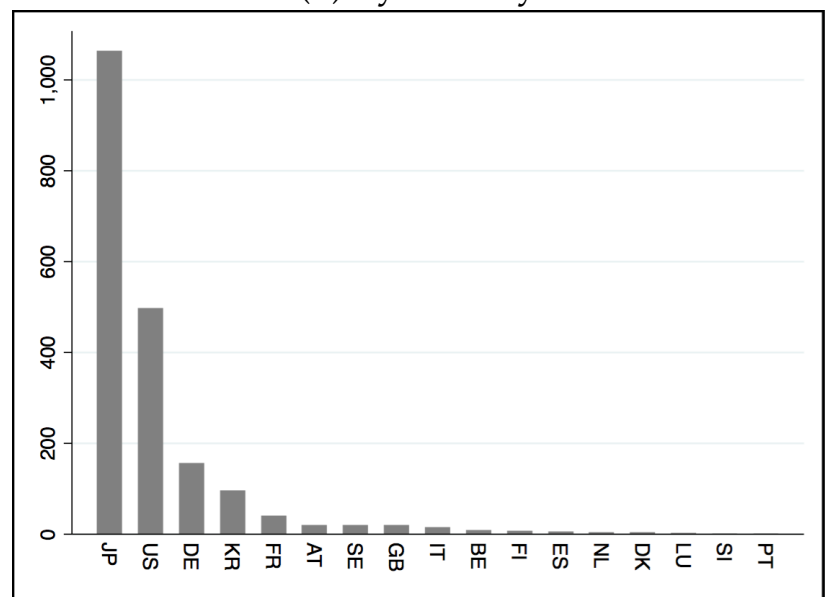

\subsubsection{Descriptive statistics of patent stocks}

We compute cumulative green patent stocks over the 1970-2005 period for our set of 17 OECD countries using the perpetual inventory method with a $10 \%$ yearly depreciation rate (Verdolini and Galeotti, 2011) to the counts of patents per sector/country/year. Figure 2a shows the average patent stock allocated to each sector across countries. ${ }^{15}$ Sectors with the largest stocks of green patenting activities are sector 27t28 (Metals), 29 (Machinery nec), 30 t33 (Office and accounting; electrical engineering; medical, precision and optical instr.) and 17t19 (Textiles, textile products, leather and footwear). In contrast, some sectors have a very low number of green patents throughout the sample, namely: 15t16 (Food, beverages and tobacco), 25 (Rubber and plastics) and 50 (Sale, maint. and repair of motor vehicles; retail sale of fuel). Figure $2 \mathrm{~b}$ gives the total number of green patents per country (aggregated over all sectors). Green innovation appears to be highly concentrated geographically: most innovation is performed by inventors in Japan, but also in the United States, Germany and South Korea, as commonly found in the literature. Finally, Figure 3 shows the evolution of the stock of green patents over time (averaged across all 17 OECD countries in our sample) for a selection of industrial sectors. Patent stocks broken down by industry increase steadily through time in most cases.

\footnotetext{
${ }^{15}$ These are the cumulative stocks of green patents weighted by the inventor fractional counts, and allocated to sectors by the concordance table.
} 
Figure 3: Green patent stocks - OECD average

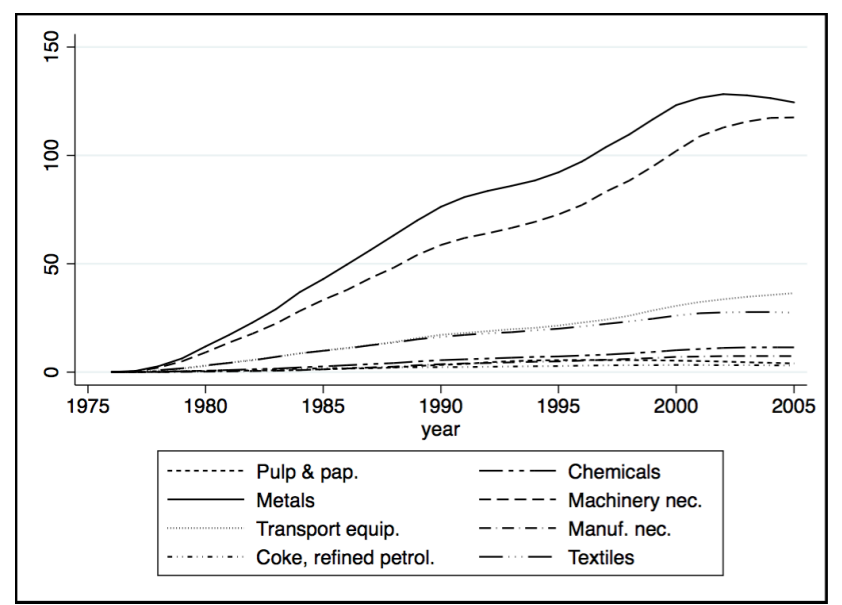

\subsection{Input demand functions}

We use production data at the industry level from the EU-KLEMS database, March 2008 version. ${ }^{16}$ This dataset is developed from supply-and-use tables to recover energy, materials and services from total intermediate inputs as provided by National Accounts, and is widely used to estimate input demand functions (see for example Mulder and de Groot, 2012; Kim and Heo, 2013; Steinbuks and Neuhoff, 2014). ${ }^{17}$ Data on input quantities and volumes per industrial sector over the 1970-2005 period are available for the following inputs: energy, material, labor and capital. Sectoral implicit prices of inputs are recalculated from input expenses $(C A P, L A B, I I E$ and $I I M)$ and volume indexes $\left(C A P_{-} Q I, L A B_{-} Q I, I I E_{-} Q I\right.$ and $\left.I I M_{-} Q I\right)$ available in the the 2008 version of EU-KLEMS. We normalize expenses and divide them by volume indexes $(1995=100)$ to obtain current energy purchaser's price indexes. ${ }^{18}$ Table 2 lists the industries included in our sample. ${ }^{19}$

Figure 4 presents the share of each input (capital, labor, materials, energy) in total costs, our

\footnotetext{
${ }^{16}$ Available at www.euklems.net.

${ }^{17} \mathrm{O}$ 'Mahony and Timmer (2009) provide a complete description of the methodologies used to build the EU-KLEMS dataset.

${ }^{18}$ Many observations in this dataset (approx. 14\%) have negative value for capital. This occurs because capital is measured as the difference between value added and labor inputs, and because in some sectors, an important fraction of labor is self-employed. As the wage rate for self-employed is typically unobserved, authors proxy it by using the wage rate of employed workers. In sectors where the latter is greater than the former, this results in negative values for capital when the value of employment exceeds the value added, and thus in negative prices for capital. As such, these observations are dropped from the estimation.

${ }^{19}$ Some sectors are aggregated to maximize sample size, while others are removed due to missing observation.
} 
Table 2: Industrial sectors included in the sample

\begin{tabular}{ll}
\hline NACE rev. 1 & Sector \\
\hline $15 \mathrm{t} 16$ & Food, beverages and tobacco \\
$17 \mathrm{t} 19$ & Textiles, textile products, leather and footwear \\
20 & Wood and products of wood and cork \\
$21 \mathrm{t} 22$ & Pulp, paper and paper products, printing and publishing \\
23 & Manufacture of coke, refined petroleum products and nuclear fuel \\
24 & Chemicals \\
25 & Rubber and plastics \\
26 & Non-metallic minerals \\
$27 \mathrm{t} 28$ & Metals \\
29 & Machinery nec \\
$30 \mathrm{t} 33$ & Office and accounting; electrical engineering; medical, precision and optical instr. \\
$34 \mathrm{t} 35$ & Transport equipment \\
$36 \mathrm{t} 37$ & Manufacturing nec; recycling \\
50 & Sale, maint. and repair of motor vehicles; retail sale of fuel \\
\hline
\end{tabular}

main dependent variable, and shows that sector 23 (Manufacture of coke, refined petroleum products and nuclear fuel) is by far the most intensive in energy as a proportion of total input costs, followed by sectors 26 (Non-metallic minerals), 24 (Chemicals), 25 (Rubber and plastics) and 27t28 (Metals).

Figure 5 plots the evolution of the cost share attributable to energy input over time for various industries. Overall, the cost share of energy tends to decrease through time and this decline is particularly strong over the first sample period, from 1980 to $1995 .{ }^{20}$ Summary statistics of our dataset are presented in Table B1 in Appendix B.

\footnotetext{
${ }^{20}$ One needs to bear in mind that being a share, this variable can also be affected by movements in the consumption of other inputs. An increase in the use of, say, labor, will mechanically affect the cost share of other inputs. A simple graphical analysis is thus limited in this respect.
} 
Figure 4: Cost shares by industrial sector - OECD average

(a) Capital

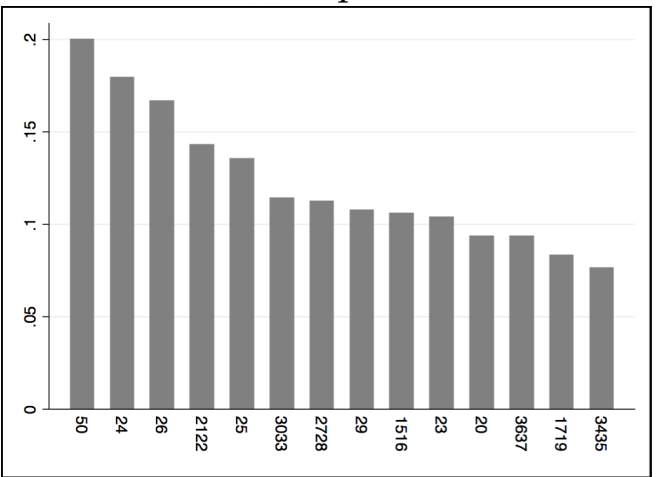

(c) Energy

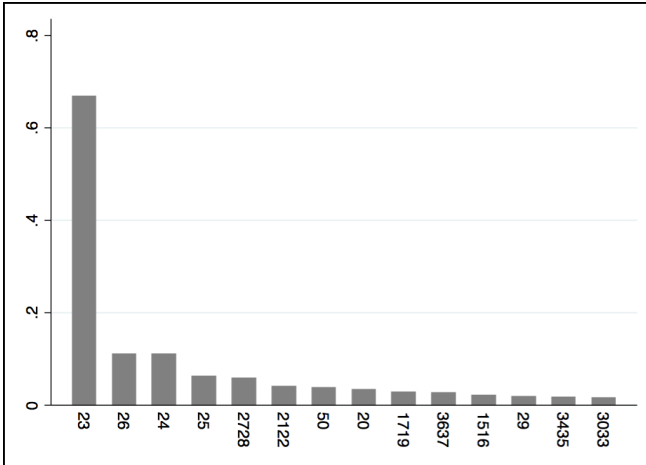

(b) Labor

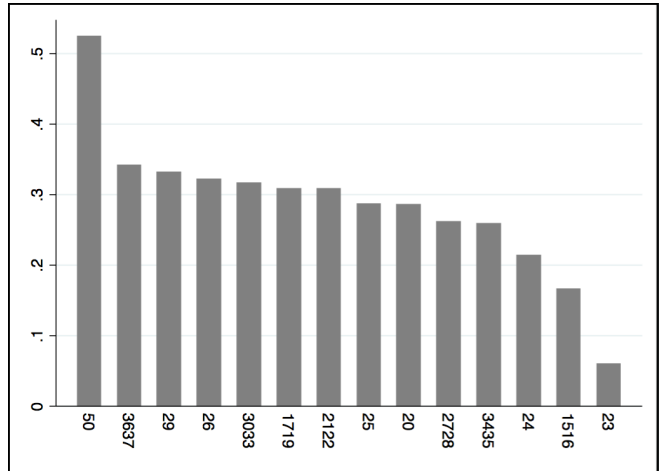

(d) Material

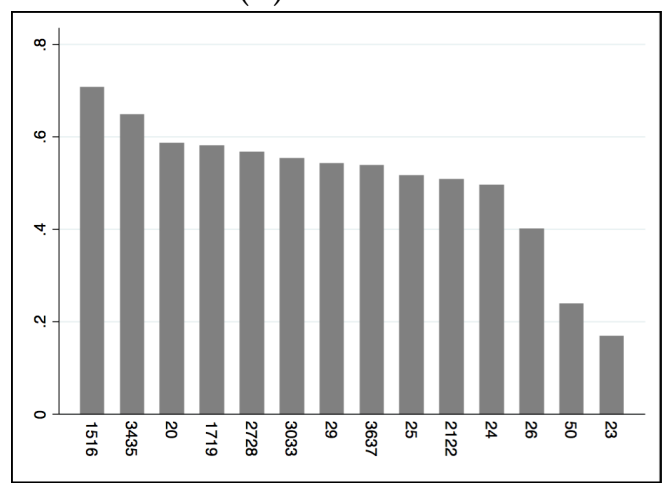


Figure 5: Cost share of energy - OECD average

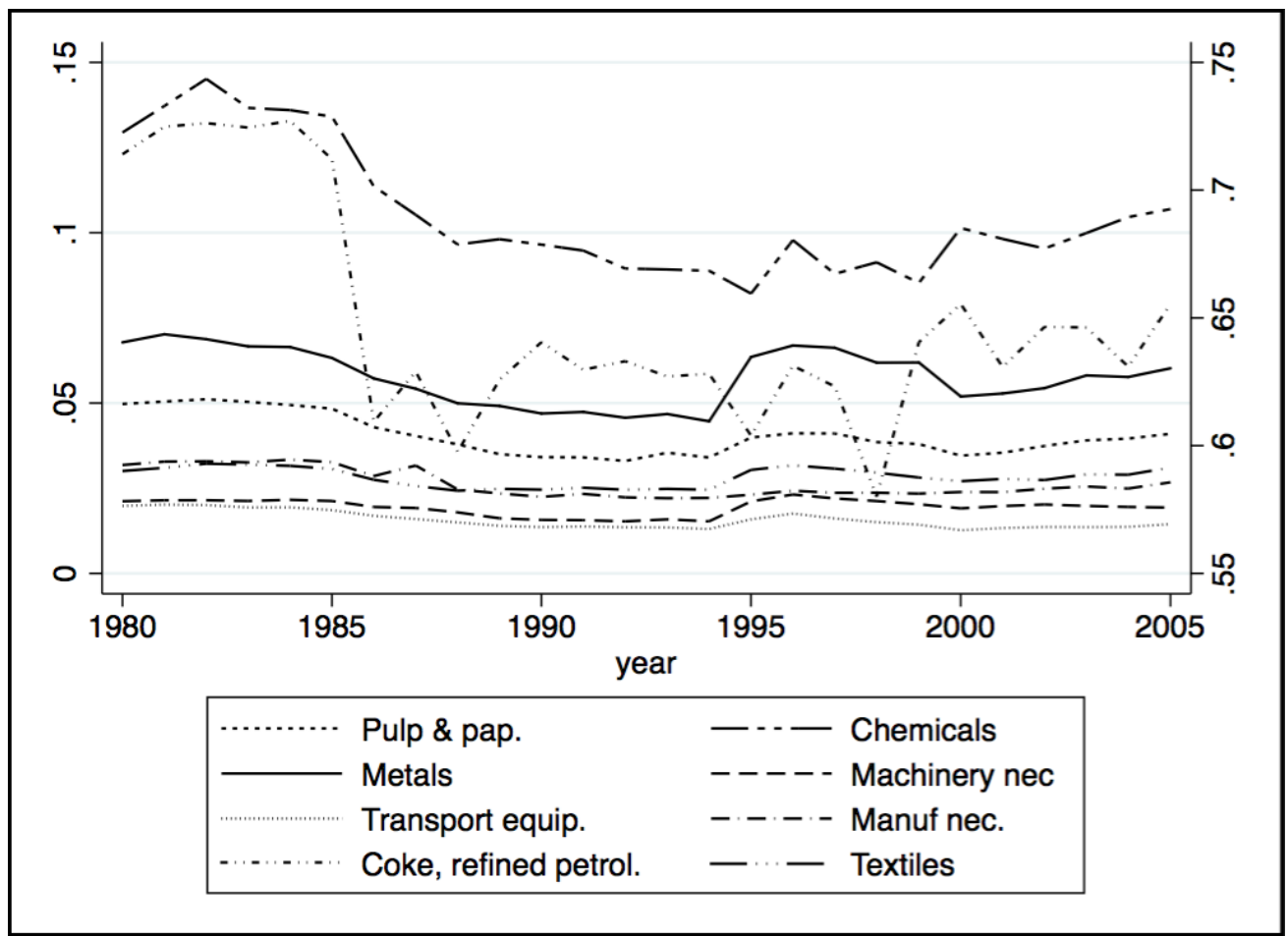

Note: Right-scale used for sector 23, Coke and refined petrol. (dash-dotted line). 


\section{Econometric Results}

In this section, we present our main results. We estimate the system of equations (6) from Section 2 sector-by-sector, and recover parameters and corresponding elasticities w.r.t. technology as defined in Equation (8). We use a one-period lag for knowledge stocks to account for potential reverse causality between green innovation and energy intensity, which simultaneously allows for a time lag between disclosure of patented innovation and effective implementation in industrial sectors. Table 3 shows the estimates of the coefficients for the cost share of energy $\left(\beta_{E G}\right.$ and $\left.\beta_{E t}\right)$, the own-price elasticity of energy $\left(\eta_{E, P E}\right)$, and the elasticity of energy intensity w.r.t. green knowledge stocks $\left(\epsilon_{E, G}\right){ }^{21,22}$ For a given sector, our sample includes 17 countries followed through 31 years. Because previous literature highlighted important differences across countries (Voigt et al., 2014), all our equations include country fixed effects to account for (country-specific) unobserved heterogeneity. ${ }^{23}$

As can be seen in Table 3, the coefficients on green knowledge stocks $\left(\beta_{E G}\right)$ are negative in 10 out of 14 sectors. These results are somewhat consistent with the findings of Popp (2001), where a negative elasticity of energy w.r.t. energy-efficient technology is observed for 8 out of 13 industrial sectors, though precise cross-study comparison is limited due to differences in the definition of sectors and aggregation levels. In terms of magnitude, our median estimate for the elasticity of green knowledge stocks $\left(\epsilon_{E, G}\right)$ is -0.027 . In other words, a $1 \%$ change in the green knowledge stock decreases the energy intensity by approx. $0.03 \%$ in the next period, with a maximum value of $2.07 \%$ found for sector 25 (Rubber and plastics), where the decrease in energy intensity is close to the sample average but with the smallest patent stock in our sample, as highlighted in Figure 2.

Interestingly, industries with the highest average cost share of energy, i.e. with the highest potential economic gains from energy productivity improvements - 23 (Man. of coke, refined petroleum prod. and nuclear fuel), 24 (Chemicals), 25 (Rubber and plastics), 26 (Non-metallic

\footnotetext{
${ }^{21}$ Appendix $\mathrm{C}$ shows estimated coefficients for additional regressors. Complete parameter estimates for other factor shares, sector by sector, are provided upon request.

${ }^{22}$ For price variables, elasticities are reported because coefficients as such provide little interpretation (Binswanger, 1974): the coefficient on the price of energy for the cost share of energy $\left(P_{e} * E\right)$, for example, mixes a direct effect (the initial increase in price increases the factor share) and a substitution effect (the subsequent decrease in quantity lowers the factor share), having thus an ambiguous effect.

${ }^{23} \mathrm{An}$ important aspect to consider is that although excluding control variables for energy subsidies, energy export restrictions, or any exogenous shocks on energy demand, our econometric framework implicitly controls for factors impacting input prices.
} 
minerals) and 27t28 (Metals) - all present a negative and statistically significant impact of green innovation. ${ }^{24}$ In contrast, some sectors seem less sensitive to green innovation, despite a large number of patents throughout our sample, as shown previously in Figure 2, namely sectors 17t19 (Textiles, textile products, Leather), 29 (Machinery nec), $30 \mathrm{t} 33$ (Office, account.; electric., medic. and precis. engin.) and $34 \mathrm{t} 35$ (Transport equipment). This could again be related to the potential gains from energy-saving innovation. Indeed, the cost share of energy in all of these sectors is lower than $2 \% .^{25}$

The coefficient associated with the time trend variable is negative and statistically significant in 8 out of 14 industries. This result suggests that autonomous technical change could play a role for the decrease in energy usage in some industries.

Table 3 and Table D1 in Appendix D present the estimates of respectively own- and crossprice elasticities for energy. The negative elasticities of energy consumption w.r.t. the price of energy, and, to a lesser extent, the price of capital, suggest that price induced input substitution also affects energy consumption in most sectors. Furthermore, the estimated values of the ownprice elasticities $\left(\eta_{E, P E}\right)$ presented in Table 3 provide us with a way to verify the properties of our cost functions. ${ }^{26}$ In Table 3, one can see that the own-price elasticity of energy is negative for all sectors, confirming that energy usage responds negatively to price changes, as expected. The magnitude of the estimated elasticities are respectively -0.538 and -0.610 for the mean and median values. A $1 \%$ change in the price of energy decreases energy demand by $0.610 \%$ in the next period at the median, close to the range of estimates previously found in the literature. ${ }^{27}$

\footnotetext{
${ }^{24}$ The average cost share of energy for these sectors amounts respectively $67 \%, 11 \%, 6 \%, 10 \%$ and $5 \%$, whereas the average for the rest of the sample is $2.6 \%$.

${ }^{25}$ The positive and significant impact in NACE 29 could be caused by the vague definition of industrial activities. As this sector is defined as a residual of machinery and equipment technologies not elsewhere classified, we expect it to cover a large number of very heterogenous activities. This could affect both the dynamics of energy intensity, as well as its corresponding allocation of patents.

${ }^{26} \mathrm{~A}$ cost function concave in input price reflects non-zero input substitution. This property of concavity of input demand is not necessarily verified in the case of the translog functional form. Derivation of input price elasticities are also provided in Appendix D.

${ }^{27}$ See for example Berndt and Wood (1975), or Popp (2001), who finds an average of -0.680 .
} 
Table 3: Baseline results

\begin{tabular}{|c|c|c|c|c|c|}
\hline Sector & $\mathrm{N}$ & $\beta_{E G}$ & $\beta_{E t}$ & $\eta_{E, P E}^{\mathbf{a}}$ & $\epsilon_{E, G}^{\mathbf{b}}$ \\
\hline Food, beverages and tobacco & 405 & $\begin{array}{l}-0.0016^{* * *} \\
(0.0005)\end{array}$ & $\begin{array}{l}0.0002^{* * * *} \\
(0.0001)\end{array}$ & -0.765 & -0.066 \\
\hline Textiles, textile products, leather & 388 & $\begin{array}{l}-0.0002 \\
(0.0005)\end{array}$ & $\begin{array}{l}0.0006 \\
(0.0001)\end{array}$ & -0.331 & -0.006 \\
\hline Wood and products of wood and cork & 393 & $\begin{array}{l}-0.0095^{* * *} \\
(0.0027)\end{array}$ & $\begin{array}{l}0.0010^{* * *} \\
(0.0002)\end{array}$ & -0.656 & -0.267 \\
\hline Pulp, paper and paper prod., print. and publish. & 405 & $\begin{array}{l}-0.0024^{* * *} \\
(0.0009)\end{array}$ & $\begin{array}{l}-0.0004^{* * *} \\
(0.0001)\end{array}$ & -0.512 & -0.053 \\
\hline Man. of coke, refined petr. prod. and nucl. fuel & 353 & $\begin{array}{l}-0.0299^{* * *} \\
(0.0054)\end{array}$ & $\begin{array}{l}-0.0001 \\
(0.0005)\end{array}$ & -0.209 & -0.044 \\
\hline Chemicals & 405 & $\begin{array}{l}-0.0064^{* * *} \\
(0.0023)\end{array}$ & $\begin{array}{l}-0.0010^{* * *} \\
(0.0004)\end{array}$ & -0.548 & -0.056 \\
\hline Rubber and plastics & 403 & $\begin{array}{l}-0.1394^{* * *} \\
(0.0402)\end{array}$ & $\begin{array}{l}0.0008^{* * *} \\
(0.0002)\end{array}$ & -0.472 & -2.066 \\
\hline Non-metallic minerals & 405 & $\begin{array}{l}-0.0029^{*} \\
(0.0016)\end{array}$ & $\begin{array}{l}-0.0004 \\
(0.0002)\end{array}$ & -0.452 & -0.027 \\
\hline Metals & 405 & $\begin{array}{l}-0.0023^{* * *} \\
(0.0006)\end{array}$ & $\begin{array}{l}-0.0003^{* *} \\
(0.0001)\end{array}$ & -0.418 & -0.040 \\
\hline Machinery nec & 405 & $\begin{array}{l}0.0006^{* *} \\
(0.0003)\end{array}$ & $\begin{array}{l}-0.0003^{* * *} \\
(0.0001)\end{array}$ & -0.643 & 0.031 \\
\hline Office, account.; electric., medic. and precis. engin. & 399 & $\begin{array}{l}0.0000 \\
(0.0003)\end{array}$ & $\begin{array}{l}-0.0001^{* *} \\
(0.0001)\end{array}$ & -0.610 & -0.001 \\
\hline Transport Equipment & 392 & $\begin{array}{l}0.0002 \\
(0.0004)\end{array}$ & $\begin{array}{l}-0.0004^{* * *} \\
(0.0001)\end{array}$ & -0.845 & 0.011 \\
\hline Manufacturing nec; recycling & 400 & $\begin{array}{l}-0.0007 \\
(0.0008)\end{array}$ & $\begin{array}{l}0.0007^{* * *} \\
(0.0001)\end{array}$ & -0.625 & -0.027 \\
\hline Sale, maint. of motor vehic.; retail sale of fuel & 388 & $\begin{array}{l}0.0078 \\
(0.0197)\end{array}$ & $\begin{array}{l}0.0007^{* * *} \\
(0.0001)\end{array}$ & -0.440 & 0.215 \\
\hline Median & & -0.0016 & -0.0001 & -0.610 & -0.027 \\
\hline $\begin{array}{l}\text { Coeff. }<0 \\
\text { Coeff. }>0\end{array}$ & & 10 & 8 & & \\
\hline Coeff. $>0$ & & 4 & 6 & & \\
\hline
\end{tabular}

Notes: ${ }^{\text {a }}$ Own-price elasticity of energy. ${ }^{\mathbf{b}}$ Short run elasticity of energy intensity w.r.t. green knowledge stock. Elasticities calculated using mean predicted input cost shares by sector as described in Section 2 . All estimations are by sector, based on the spec. with domestic stocks of green Triadic patents, with country FE. Standard errors in parentheses. $\mathrm{p}^{* * *} \leq 0.01, \mathrm{p}^{* *} \leq 0.05, \mathrm{p}^{*} \leq 0.1$ 


\subsection{Alternative specifications}

In this section we present three alternative specifications. First, hinging upon the difference in the trend of energy intensity through time observed in Figure 1, we distinguish between the 1975-1990 and the 1991-2005 period by interacting our variables for technology with an indicator variable for each of the periods. Results are presented in Table 4. As can be seen by the magnitude of the coefficients and their statistical significance, green patented innovation seems to have a stronger effect in more recent years, with a median elasticity of -0.057 , than in earlier periods, with a corresponding elasticity of -0.011 . We also find a negative, statistically significant impact of green innovation in the same subset of industries as our baseline specification, for both time periods.

Second, we include the stock of patents not identified as green, calculated by subtracting the stock of green patents from the total stock of patents. This affords an indirect mean to control for the robustness of our identification of patents expected to affect energy intensity, as well as to account for potential cyclical trends in the number of general patent applications. Estimates are presented in Table 5. Although multicollinearity could reduce the statistical significance of some estimated coefficients, we observe that non-green patents do not decrease energy intensity as consistently as green patents. ${ }^{28}$ In terms of magnitude, the median impact of non-green patents is estimated at -0.01 , roughly a third of the corresponding statistic for green innovation. Furthermore, estimates for green innovation remain close to our baseline specification: here, the median elasticity of energy intensity w.r.t. green patents amounts -0.030 , compared to -0.027 estimated previously.

Finally, we present the result of estimations with patent stocks composed only by the subset of technologies identified as directly related to energy consumption technologies by Popp (2001), in order to control the robustness of our definition of green patents. Results, presented in Table 6 , show that our estimates are robust to this alternative specification, with a median elasticity of -0.043 , of slightly greater magnitude than in our baseline.

\footnotetext{
${ }^{28}$ The correlation between the log of the stock of green and non-green patents, as included in our regressions, equals 0.8 .
} 
Table 4: 1975-1990 vs. 1991-2005

\begin{tabular}{|c|c|c|c|c|c|c|c|}
\hline Sector & $\mathrm{N}$ & $\beta_{E G, 1}$ & $\beta_{E G, 2}$ & $\beta_{E t, 1}$ & $\beta_{E t, 2}$ & $\epsilon_{E, G 1}^{\mathbf{a}}$ & $\epsilon_{E, G 2}^{\mathbf{b}}$ \\
\hline Food, bev. and tob. & 405 & $\begin{array}{l}-0.0004 \\
(0.0007)\end{array}$ & $\begin{array}{l}-0.0014^{* * *} \\
(0.0004)\end{array}$ & $\begin{array}{l}0.0001 \\
(0.0001)\end{array}$ & $\begin{array}{l}0.0004^{* * *} \\
(0.0001)\end{array}$ & -0.019 & -0.060 \\
\hline Text, text. prod, leath. & 388 & $\begin{array}{l}0.0024^{* * *} \\
(0.0005)\end{array}$ & $\begin{array}{l}0.0013^{* * *} \\
(0.0004)\end{array}$ & $\begin{array}{l}-0.0003^{* * *} \\
(0.0001)\end{array}$ & $\begin{array}{l}0.0007^{* * * *} \\
(0.0001)\end{array}$ & 0.079 & 0.045 \\
\hline Wood and prod. of wood & 393 & $\begin{array}{l}-0.0008 \\
(0.0037)\end{array}$ & $\begin{array}{l}-0.0048^{* *} \\
(0.0022)\end{array}$ & $\begin{array}{l}-0.0003^{* *} \\
(0.0001)\end{array}$ & $\begin{array}{l}0.0008^{* * *} \\
(0.0002)\end{array}$ & -0.022 & -0.135 \\
\hline Pulp, pap., print. and publ. & 405 & $\begin{array}{l}-0.0029^{* * *} \\
(0.0011)\end{array}$ & $\begin{array}{l}-0.0039^{* * *} \\
(0.0008)\end{array}$ & $\begin{array}{l}-0.0002 \\
(0.0001)\end{array}$ & $\begin{array}{c}-0.0002 \\
(0.0002)\end{array}$ & -0.065 & -0.086 \\
\hline Man. of coke \& petr. & 353 & $\begin{array}{l}-0.0276^{* * *} \\
(0.0051)\end{array}$ & $\begin{array}{l}-0.0372^{* * *} \\
(0.0043)\end{array}$ & $\begin{array}{l}-0.0001 \\
(0.0005)\end{array}$ & $\begin{array}{l}0.0019^{* *} \\
(0.0007)\end{array}$ & -0.041 & -0.055 \\
\hline Chemicals & 405 & $\begin{array}{l}-0.0080^{* * *} \\
(0.0025)\end{array}$ & $\begin{array}{l}-0.0132^{* * *} \\
(0.0019)\end{array}$ & $\begin{array}{l}0.0002 \\
(0.0003)\end{array}$ & $\begin{array}{l}0.0017^{* * * *} \\
(0.0004)\end{array}$ & -0.070 & -0.115 \\
\hline Rubber and plastics & 403 & $\begin{array}{l}0.0110 \\
(0.0463)\end{array}$ & $\begin{array}{l}-0.1208^{* * *} \\
(0.0387)\end{array}$ & $\begin{array}{l}0.0003^{*} \\
(0.0002)\end{array}$ & $\begin{array}{l}0.0015^{* * *} \\
(0.0003)\end{array}$ & 0.162 & -1.779 \\
\hline Non-metal. minerals & 405 & $\begin{array}{l}-0.0039^{* *} \\
(0.0017)\end{array}$ & $\begin{array}{l}-0.0085^{* * *} \\
(0.0013)\end{array}$ & $\begin{array}{l}-0.0005^{* *} \\
(0.0002)\end{array}$ & $\begin{array}{l}0.0010^{* * *} \\
(0.0003)\end{array}$ & -0.035 & -0.076 \\
\hline Metals & 405 & $\begin{array}{l}-0.0024^{* * *} \\
(0.0006)\end{array}$ & $\begin{array}{l}-0.0039^{* * *} \\
(0.0005)\end{array}$ & $\begin{array}{l}-0.0002^{*} \\
(0.0001)\end{array}$ & $\begin{array}{l}0.0005^{* * *} \\
(0.0002)\end{array}$ & -0.041 & -0.066 \\
\hline Machinery nec & 405 & $\begin{array}{l}0.0003 \\
(0.0003)\end{array}$ & $\begin{array}{l}-0.0003 \\
(0.0003)\end{array}$ & $\begin{array}{l}-0.0001^{*} \\
(0.0001)\end{array}$ & $\begin{array}{l}0.0000 \\
(0.0001)\end{array}$ & 0.019 & -0.017 \\
\hline Office, acc.; elec. eng. & 399 & $\begin{array}{l}-0.0001 \\
(0.0004)\end{array}$ & $\begin{array}{l}-0.0004 \\
(0.0003)\end{array}$ & $\begin{array}{l}-0.0001^{*} \\
(0.0001)\end{array}$ & $\begin{array}{l}0.0001 \\
(0.0001)\end{array}$ & -0.004 & -0.026 \\
\hline Transport Equipment & 392 & $\begin{array}{l}0.0001 \\
(0.0005)\end{array}$ & $\begin{array}{l}-0.0008^{* *} \\
(0.0003)\end{array}$ & $\begin{array}{l}0.0000 \\
(0.0001)\end{array}$ & $\begin{array}{l}-0.0001 \\
(0.0001)\end{array}$ & 0.004 & -0.047 \\
\hline Manuf. nec; recycl. & 400 & $\begin{array}{l}0.0005 \\
(0.0010)\end{array}$ & $\begin{array}{l}0.0007 \\
(0.0007)\end{array}$ & $\begin{array}{l}0.0000 \\
(0.0001)\end{array}$ & $\begin{array}{l}0.0007^{* * * *} \\
(0.0001)\end{array}$ & 0.021 & 0.026 \\
\hline Sale \& maint. of mot. vehic. & 388 & $\begin{array}{l}0.0213 \\
(0.0222)\end{array}$ & $\begin{array}{l}0.0333^{*} \\
(0.0200)\end{array}$ & $\begin{array}{l}0.0003^{* *} \\
(0.0001)\end{array}$ & $\begin{array}{l}0.0008^{* * *} \\
(0.0002)\end{array}$ & 0.589 & 0.922 \\
\hline Median & & -0.0003 & -0.0026 & -0.0001 & 0.0007 & -0.011 & -0.057 \\
\hline
\end{tabular}

Notes: ${ }^{a}$ Short run elasticity of energy intensity w.r.t. green knowledge stock, 1975-1990. ${ }^{\text {b }}$ Short run elasticity of energy intensity w.r.t. green knowledge stock, 1991-2005. $\beta_{E G, 1} / \beta_{t, 1}$ and $\beta_{E G, 2} / \beta_{t, 2}$ correspond to the first (1975-1990) and second (1991-2005) period respectively. Elasticities calculated using mean predicted input cost shares by sector as described in Section 2. All estimations are by sector, based on the spec. with domestic, green stocks of Triadic patents, with country FE. Standard errors in parentheses. $\mathrm{p}^{* *} \leq 0.01, \mathrm{p}^{* *} \leq 0.05, \mathrm{p}^{*} \leq 0.1$. 
Table 5: Green vs. non-green patents

\begin{tabular}{|c|c|c|c|c|c|}
\hline Sector & $\beta_{E G}$ & $\beta_{E N G}$ & $\beta_{E t}$ & $\epsilon_{E, G}^{\mathbf{a}}$ & $\epsilon_{E, N G}^{\mathbf{b}}$ \\
\hline Food, bev. and tob. & $\begin{array}{l}-0.0014^{* * *} \\
(0.0005)\end{array}$ & $\begin{array}{l}-0.0003 \\
(0.0003)\end{array}$ & $\begin{array}{l}0.0002^{* * *} \\
(0.0001)\end{array}$ & -0.061 & -0.011 \\
\hline Text, text. prod, leath. & $\begin{array}{l}-0.0009 \\
(0.0010)\end{array}$ & $\begin{array}{l}0.0006 \\
(0.0008)\end{array}$ & $\begin{array}{l}0.0006^{* * *} \\
(0.0001)\end{array}$ & -0.030 & 0.022 \\
\hline Wood and prod. of wood & $\begin{array}{l}-0.0073^{* *} \\
(0.0031)\end{array}$ & $\begin{array}{l}-0.0015 \\
(0.0012)\end{array}$ & $\begin{array}{l}0.0010^{* * *} \\
(0.0002)\end{array}$ & -0.205 & -0.042 \\
\hline Pulp, pap., print. and publ. & $\begin{array}{l}-0.0036^{* * *} \\
(0.0011)\end{array}$ & $\begin{array}{l}0.0014^{* *} \\
(0.0007)\end{array}$ & $\begin{array}{l}-0.0004^{* * *} \\
(0.0001)\end{array}$ & -0.079 & 0.031 \\
\hline Man. of coke \& petr. & $\begin{array}{l}-0.0139^{*} \\
(0.0079)\end{array}$ & $\begin{array}{l}-0.0119^{* * *} \\
(0.0043)\end{array}$ & $\begin{array}{l}0.0004 \\
(0.0005)\end{array}$ & -0.020 & -0.017 \\
\hline Chemicals & $\begin{array}{l}-0.0016 \\
(0.0031)\end{array}$ & $\begin{array}{l}-0.0046^{* *} \\
(0.0020)\end{array}$ & $\begin{array}{l}-0.0012^{* * *} \\
(0.0004)\end{array}$ & -0.014 & -0.041 \\
\hline Rubber and plastics & $\begin{array}{l}-0.2638^{* * *} \\
(0.0443)\end{array}$ & $\begin{array}{l}0.0068^{* * *} \\
(0.0012)\end{array}$ & $\begin{array}{l}0.0004^{* *} \\
(0.0002)\end{array}$ & -3.937 & 0.101 \\
\hline Non-metal. minerals & $\begin{array}{l}0.0014 \\
(0.0024)\end{array}$ & $\begin{array}{l}-0.0039^{* * *} \\
(0.0015)\end{array}$ & $\begin{array}{l}-0.0004^{*} \\
(0.0002)\end{array}$ & 0.013 & -0.036 \\
\hline Metals & $\begin{array}{l}-0.0017 \\
(0.0018)\end{array}$ & $\begin{array}{l}-0.0006 \\
(0.0016)\end{array}$ & $\begin{array}{l}-0.0003^{* *} \\
(0.0001)\end{array}$ & -0.029 & -0.010 \\
\hline Machinery nec & $\begin{array}{l}-0.0002 \\
(0.0007)\end{array}$ & $\begin{array}{l}0.0007 \\
(0.0006)\end{array}$ & $\begin{array}{l}-0.0002^{* * *} \\
(0.0001)\end{array}$ & -0.010 & 0.040 \\
\hline Office, acc.; elec. eng. & $\begin{array}{l}-0.0006 \\
(0.0006)\end{array}$ & $\begin{array}{l}0.0006 \\
(0.0005)\end{array}$ & $\begin{array}{l}-0.0001^{* *} \\
(0.0001)\end{array}$ & -0.039 & 0.037 \\
\hline Transport Equipment & $\begin{array}{l}-0.0011^{*} \\
(0.0006)\end{array}$ & $\begin{array}{l}0.0014^{* * *} \\
(0.0005)\end{array}$ & $\begin{array}{l}-0.0004^{* * *} \\
(0.0001)\end{array}$ & -0.065 & 0.080 \\
\hline Manuf. nec; recycl. & $\begin{array}{l}-0.0002 \\
(0.0010)\end{array}$ & $\begin{array}{l}-0.0006 \\
(0.0008)\end{array}$ & $\begin{array}{l}0.0007^{* * *} \\
(0.0001)\end{array}$ & -0.006 & -0.024 \\
\hline Sale \& maint. of mot. vehic. & $\begin{array}{l}0.0415^{*} \\
(0.0240)\end{array}$ & $\begin{array}{l}-0.0039^{* *} \\
(0.0016)\end{array}$ & $\begin{array}{l}0.0008^{* * *} \\
(0.0001)\end{array}$ & 1.145 & -0.107 \\
\hline Median & -0.0013 & -0.0004 & 0.0000 & -0.030 & -0.010 \\
\hline
\end{tabular}

Notes: ${ }^{a}$ Short run elasticity of energy intensity w.r.t. green knowledge stock. ${ }^{\mathbf{b}}$ Short run elasticity of energy intensity w.r.t. non-green knowledge stock. $\beta_{E G}$ and $\beta_{E N G}$ correspond to green and non-green technologies respectively. Elasticities calculated using mean predicted input cost shares by sector as described in Section 2. All estimations are by sector, based on the spec. with domestic, green stocks of granted patents, with country FE. Standard errors in parentheses. $\mathrm{p}^{* * *} \leq 0.01, \mathrm{p}^{* *} \leq 0.05, \mathrm{p}^{*} \leq 0.1$. 
Table 6: Alternative patent count as in Popp (2001)

\begin{tabular}{|c|c|c|c|c|c|}
\hline Sector & $\mathrm{N}$ & $\beta_{E G}$ & $\beta_{E t}$ & $\eta_{E, P E}^{\mathbf{a}}$ & $\epsilon_{E, G}^{\mathbf{b}}$ \\
\hline Food, beverages and tobacco & 405 & $\begin{array}{l}-0.0015^{* * *} \\
(0.0005)\end{array}$ & $\begin{array}{l}0.0002^{* * *} \\
(0.0001)\end{array}$ & -0.766 & -0.064 \\
\hline Textiles, textile products, leather & 388 & $\begin{array}{l}-0.0002 \\
(0.0005)\end{array}$ & $\begin{array}{l}0.0006^{* * *} \\
(0.0001)\end{array}$ & -0.331 & -0.006 \\
\hline Wood and products of wood and cork & 393 & $\begin{array}{l}-0.0374^{* * * *} \\
(0.0109)\end{array}$ & $\begin{array}{l}0.0008^{* * *} \\
(0.0001)\end{array}$ & -0.633 & -1.043 \\
\hline Pulp, paper and paper prod., print. and publish. & 405 & $\begin{array}{l}-0.0028 \\
(0.0018)\end{array}$ & $\begin{array}{l}-0.0005^{* * * *} \\
(0.0001)\end{array}$ & -0.502 & -0.061 \\
\hline Man. of coke, refined petr. prod. and nucl. fuel & 353 & $\begin{array}{l}-0.0206^{* * *} \\
(0.0072)\end{array}$ & $\begin{array}{l}-0.0014^{* * *} \\
(0.0004)\end{array}$ & -0.214 & -0.030 \\
\hline Chemicals & 405 & $\begin{array}{l}-0.0059^{* *} \\
(0.0023)\end{array}$ & $\begin{array}{l}-0.0011^{* * *} \\
(0.0004)\end{array}$ & -0.547 & -0.051 \\
\hline Rubber and plastics & 403 & $\begin{array}{l}-0.1846^{* * *} \\
(0.0445)\end{array}$ & $\begin{array}{l}0.0008^{* * *} \\
(0.0002)\end{array}$ & -0.465 & -2.739 \\
\hline Non-metallic minerals & 405 & $\begin{array}{l}-0.0098^{* * *} \\
(0.0019)\end{array}$ & $\begin{array}{l}0.0001 \\
(0.0002)\end{array}$ & -0.447 & -0.089 \\
\hline Metals & 405 & $\begin{array}{l}-0.0025^{* * *} \\
(0.0006)\end{array}$ & $\begin{array}{l}-0.0002^{* *} \\
(0.0001)\end{array}$ & -0.417 & -0.043 \\
\hline Machinery nec & 405 & $\begin{array}{l}0.0005^{* *} \\
(0.0003)\end{array}$ & $\begin{array}{l}-0.0003^{* * *} \\
(0.0001)\end{array}$ & -0.643 & 0.031 \\
\hline Office, account.; electric., medic. and precis. engin. & 399 & $\begin{array}{l}-0.0002 \\
(0.0003)\end{array}$ & $\begin{array}{l}-0.0001^{*} \\
(0.0001)\end{array}$ & -0.608 & -0.015 \\
\hline Transport Equipment & 392 & $\begin{array}{l}0.0001 \\
(0.0004)\end{array}$ & $\begin{array}{l}-0.0004^{* * *} \\
(0.0001)\end{array}$ & -0.846 & 0.006 \\
\hline Manufacturing nec; recycling & 400 & $\begin{array}{l}-0.0008 \\
(0.0008)\end{array}$ & $\begin{array}{l}0.0007^{* * *} \\
(0.0001)\end{array}$ & -0.626 & -0.029 \\
\hline Median & & -0.0025 & -0.0001 & -0.547 & -0.043 \\
\hline
\end{tabular}

Notes: ${ }^{\text {a }}$ Own-price elasticity of energy. ${ }^{\mathbf{b}}$ Short run elasticity of energy intensity w.r.t. green knowledge stock. Elasticities calculated using mean predicted input cost shares by sector as described in Section 2. All estimations are by sector, based on the spec. with domestic stocks of Triadic patents as defined in Popp (2001), with country FE. Standard errors in parentheses. $\mathrm{p}^{* * *} \leq 0.01, \mathrm{p}^{* *} \leq 0.05, \mathrm{p}^{*} \leq 0.1$. Sector 50 missing because no patent allocated to this sector. 


\section{Conclusion}

This paper aimed at quantifying the impact of green innovation on energy intensity of industries using patent statistics in a multi-sector, multi-country setting. By matching sector-specific green knowledge stocks based on Triadic Patent Families with input cost functions using EUKLEMS data, we have found green innovation to be energy-saving in a majority of industries, with a median elasticity of -0.03 . Hence, a $1 \%$ increase in green patenting activities in a given sector is associated with a $0.03 \%$ decline in energy intensity. We find a statistically significant impact in all energy intensive industries. The largest impacts are found in those industries, and in more recent years. In addition, non-green patenting activities are found to have an effect of smaller magnitude - roughly a third - than green patenting ones. In parallel, our estimates for own- and cross-price elasticities suggest a role for price induced input substitution in the observed decrease in energy intensity. Our findings are robust to a more restrictive definition of patents expected to affect energy usage.

The main purpose of our results is to inform policymakers about the magnitude of the impact of green innovation on energy intensity across industrial sectors, thereby contributing to the empirical body of evidence in favour of policies supporting green R\&D. However, our empirical estimates of the impact of technological change on energy intensity could also serve as an input for forecasting energy consumption and carbon emissions in CGE models. Our findings could thus contribute to reduce the existing gap between the empirical and the modeling sub-stream of the literature on technological change and the environment (Pizer and Popp, 2008; Fisher-Vanden et al., 2014). We close by suggesting several extensions for future work. First, future contributions could include more factors potentially affecting energy consumption, such as energy policies for example. Although these are implicitly captured by the price variables in our estimated equations, inasmuch as they influence input demand, incorporating explicitly variables measuring energy policies could help identifying the role of policymaking more clearly. Second, our measure of elasticity captures the direct impact of green patents. Long term elasticities are likely to be of greater magnitude as effects accumulate through time. A more complete analysis of these long term effects remains an important research question, but would require to measure adequately spillover effects, both across industries and time, for example in a general equilibrium setting. 


\section{Appendix A Parameter Derivation}

Appendix A.1 Elasticity of energy intensity w.r.t. technology

$$
\begin{aligned}
\epsilon_{E, G} & =\frac{\partial \ln (E / Y)}{\partial \ln G}=\frac{\partial(E / Y)}{\partial \ln G} \frac{Y}{E}=\frac{\partial\left(\left(P_{Y} / P_{E}\right) s_{E}\right)}{\partial \ln G} \frac{Y}{E} \\
& =\frac{\partial s_{E}}{\partial \ln G} \frac{Y}{E} \frac{P_{Y}}{P_{E}}=\beta_{E G} \frac{P_{Y} Y}{P_{E} E}=\beta_{E G} \frac{1}{s_{E}}=\frac{\beta_{E G}}{s_{E}}
\end{aligned}
$$

\section{Appendix A.2 Standard error of price elasticities}

- Cross-price elasticities:

$$
\begin{gathered}
V\left(\eta_{i j}\right)=V\left(\frac{\beta_{i j}}{s_{i}}+s_{j}\right)=\frac{1}{s_{i}^{2}} V\left(\beta_{i j}\right) \\
S E\left(\eta_{i j}\right)=\sqrt{V\left(\eta_{i j}\right)}=\frac{1}{s_{i}} S E\left(\beta_{i j}\right)
\end{gathered}
$$

- Own-price elasticities:

$$
S E\left(\eta_{i i}\right)=\sqrt{V\left(\eta_{i i}\right)}=\frac{1}{s_{i}} S E\left(\beta_{i i}\right)
$$




\section{Appendix B Sample Statistics}

Table B1: Descriptive statistics of the dataset

\begin{tabular}{|c|c|c|c|c|c|c|}
\hline Variable & Units & Obs & Mean & Std. Dev. & Min & Max \\
\hline \multicolumn{7}{|c|}{ Green patent stocks } \\
\hline Year & & 12,409 & 1987.7 & 10.4 & 1970 & 2005 \\
\hline Green Patent Stock & Patent counts & 8,532 & 18.8 & 90.35 & 0.00 & 1,339 \\
\hline \multicolumn{7}{|c|}{ Value of output and input compensation } \\
\hline Output & cst. mil. LCU & 7,067 & $2,532,792$ & $1.05^{*} 10^{7}$ & 0.00 & $1.92^{*} 10^{8}$ \\
\hline Capital & cst. mil. LCU & 7,067 & 315,443 & $1,360,162$ & 0.00 & $2.80^{*} 10^{7}$ \\
\hline Labor & cst. mil. LCU & 7,067 & 431,445 & $1,652,491$ & 0.00 & $2.46^{*} 10^{7}$ \\
\hline Energy & cst. mil. LCU & 6,124 & 188,256 & $1,216,873$ & 0.00 & $3.00^{*} 10^{7}$ \\
\hline Materials & cst. mil. LCU & 6,124 & $1,499,036$ & $6,210,379$ & 0.00 & $1.07^{*} 10^{8}$ \\
\hline \multicolumn{7}{|c|}{ Quantity indexes } \\
\hline Output & Index & 7,067 & 0.941 & 0.352 & 0.017 & 5.09 \\
\hline Capital & Index & 6,773 & 0.928 & 0.381 & 0.014 & 7.56 \\
\hline Labor & Index & 6,118 & 1.042 & 0.257 & 0.104 & 3.46 \\
\hline Energy & Index & 6,047 & 1.078 & 1.429 & 0.002 & 63.5 \\
\hline Materials & Index & 6,047 & 0.962 & 0.404 & 0.017 & 5.97 \\
\hline \multicolumn{7}{|c|}{ Nominal price indexes } \\
\hline Output & Index & 7,036 & 0.875 & 0.314 & 0.05 & 4.435 \\
\hline Capital & Index & 6,742 & 1.114 & 1.691 & 0.00 & 36.24 \\
\hline Labor & Index & 6,104 & 0.874 & 0.388 & 0.02 & 5.537 \\
\hline Energy & Index & 6,036 & 1.049 & 1.024 & 0.03 & 27.88 \\
\hline Materials & Index & 6,036 & 0.986 & 2.483 & 0.07 & 97.32 \\
\hline \multicolumn{7}{|c|}{ Total costs and cost shares } \\
\hline Total costs & cst. mil. LCU & $9^{\prime} 635$ & $2,290,811$ & $9,293,264$ & 0.00 & $1.6^{*} 10^{8}$ \\
\hline Capital & Percentage & $6^{\prime} 911$ & 0.121 & 0.065 & 0.00 & 0.589 \\
\hline Labor & Percentage & $6^{\prime} 911$ & 0.286 & 0.123 & 0.01 & 0.788 \\
\hline Energy & Percentage & $6^{\prime} 911$ & 0.087 & 0.180 & 0.00 & 0.973 \\
\hline Materials & Percentage & $6^{\prime} 911$ & 0.505 & 0.164 & 0.00 & 0.858 \\
\hline
\end{tabular}

Notes: Input compensation and Value of output are in constant mill. local currency. Quantities are indexes $(1995=1)$. Price are calc. from normalized input compensation and indexes of quantities $(1995=1)$. Cost shares are calculated from Total Costs (TC), calc. as the sum of all input compensation 


\section{Appendix C Additional Parameter Estimates}

Table C1: Coefficient on price indexes and output level, cost share of energy

\begin{tabular}{|c|c|c|c|c|}
\hline Sector & $\beta_{E E}$ & $\beta_{E K}$ & $\beta_{E L}$ & $\beta_{E Y}$ \\
\hline Food, beverages and tobacco & $\begin{array}{c}0.0061^{* * *} \\
(0.0008)\end{array}$ & $\begin{array}{c}-0.0031^{* * *} \\
(0.0008)\end{array}$ & $\begin{array}{c}-0.0029^{* * *} \\
(0.0008)\end{array}$ & $\begin{array}{c}0.0001 \\
(0.0007)\end{array}$ \\
\hline Textiles, textile products,leather & $\begin{array}{c}0.0173^{* * *} \\
(0.0014)\end{array}$ & $\begin{array}{l}-0.0004 \\
(0.0007)\end{array}$ & $\begin{array}{c}-0.0169^{* * *} \\
(0.0013)\end{array}$ & $\begin{array}{c}0.0011 \\
(0.0010)\end{array}$ \\
\hline Wood and products of wood and cork & $\begin{array}{c}0.0098^{* * *} \\
(0.0021)\end{array}$ & $\begin{array}{c}-0.0042^{* * *} \\
(0.0009)\end{array}$ & $\begin{array}{c}-0.0056^{* * *} \\
(0.0020)\end{array}$ & $\begin{array}{l}0.0036^{* *} \\
(0.0018)\end{array}$ \\
\hline Pulp, paper and paper prod., print. and publish. & $\begin{array}{c}0.0199^{* * *} \\
(0.0018)\end{array}$ & $\begin{array}{c}-0.0115^{* * *} \\
(0.0014)\end{array}$ & $\begin{array}{c}-0.0084^{* * *} \\
(0.0020)\end{array}$ & $\begin{array}{l}0.0032^{* *} \\
(0.0014)\end{array}$ \\
\hline Man. of coke, refined petrol. prod. and nucl. fuel & $\begin{array}{c}0.0651^{* * *} \\
(0.0035)\end{array}$ & $\begin{array}{c}-0.0433^{* * *} \\
(0.0027)\end{array}$ & $\begin{array}{c}-0.0218^{* * *} \\
(0.0020)\end{array}$ & $\begin{array}{c}0.0531^{* * *} \\
(0.0049)\end{array}$ \\
\hline Chemicals & $\begin{array}{c}0.0389^{* * * *} \\
(0.0028)\end{array}$ & $\begin{array}{c}-0.0244^{* * *} \\
(0.0019)\end{array}$ & $\begin{array}{c}-0.0146^{* * *} \\
(0.0019)\end{array}$ & $\begin{array}{c}0.0217^{* * * *} \\
(0.0038)\end{array}$ \\
\hline Rubber and plastics & $\begin{array}{c}0.0368^{* * *} \\
(0.0033)\end{array}$ & $\begin{array}{c}-0.0146^{* * *} \\
(0.0017)\end{array}$ & $\begin{array}{c}-0.0221^{* * *} \\
(0.0032)\end{array}$ & $\begin{array}{c}0.0012 \\
(0.0025)\end{array}$ \\
\hline Non-metallic minerals & $\begin{array}{c}0.0477^{* * *} \\
(0.0026)\end{array}$ & $\begin{array}{c}-0.0266^{* * *} \\
(0.0021)\end{array}$ & $\begin{array}{c}-0.0211^{* * *} \\
(0.0023)\end{array}$ & $\begin{array}{c}0.0110^{* * *} \\
(0.0025)\end{array}$ \\
\hline Metals & $\begin{array}{c}0.0314^{* * *} \\
(0.0018)\end{array}$ & $\begin{array}{c}-0.0107^{* * *} \\
(0.0011)\end{array}$ & $\begin{array}{c}-0.0207^{* * * *} \\
(0.0018)\end{array}$ & $\begin{array}{c}0.0083^{* * * *} \\
(0.0013)\end{array}$ \\
\hline Machinery nec. & $\begin{array}{c}0.0059^{* * *} \\
(0.0009)\end{array}$ & $\begin{array}{c}-0.0015^{* * *} \\
(0.0006)\end{array}$ & $\begin{array}{c}-0.0044^{* * *} \\
(0.0010)\end{array}$ & $\begin{array}{c}0.0038^{* * *} \\
(0.0006)\end{array}$ \\
\hline Office, account.; electric., medic. and precis. engin. & $\begin{array}{c}0.0056^{* * *} \\
(0.0007)\end{array}$ & $\begin{array}{c}-0.0038^{* * *} \\
(0.0005)\end{array}$ & $\begin{array}{c}-0.0018^{* *} \\
(0.0007)\end{array}$ & $\begin{array}{l}0.0014^{* *} \\
(0.0006)\end{array}$ \\
\hline Transport equipment & $\begin{array}{c}0.0030^{* * * *} \\
(0.0005)\end{array}$ & $\begin{array}{c}-0.0025^{* * *} \\
(0.0003)\end{array}$ & $\begin{array}{c}-0.0005 \\
(0.0006)\end{array}$ & $\begin{array}{c}0.0023^{* * * *} \\
(0.0007)\end{array}$ \\
\hline Manufacturing nec; recycling & $\begin{array}{c}0.0092^{* * *} \\
(0.0013)\end{array}$ & $\begin{array}{l}0.0014^{*} \\
(0.0008)\end{array}$ & $\begin{array}{c}-0.0106^{* * *} \\
(0.0013)\end{array}$ & $\begin{array}{c}-0.0055^{* * *} \\
(0.0013)\end{array}$ \\
\hline Sale, maint. of motor vehic.; retail sale of fuel & $\begin{array}{c}0.0170^{* * *} \\
(0.0016)\end{array}$ & $\begin{array}{c}-0.0055^{* * *} \\
(0.0009)\end{array}$ & $\begin{array}{c}-0.0115^{* * *} \\
(0.0016)\end{array}$ & $\begin{array}{c}-0.0092 \\
(0.0015)\end{array}$ \\
\hline Mean & 0.0224 & -0.0108 & -0.0116 & 0.0069 \\
\hline Median & 0.0171 & -0.0049 & -0.0110 & 0.0027 \\
\hline
\end{tabular}

Notes: Estimates by sector, based on the spec. with domestic, green stocks of granted patents, with country FE. Sectors $51,52,60 \mathrm{t} 63,64,70,71 \mathrm{t} 74$ missing because of zero green capital stock (see conc. table for details). Standard errors in parentheses. $\mathrm{p}^{* *} \leq 0.01, \mathrm{p}^{* *} \leq 0.05, \mathrm{p}^{*} \leq 0.1$. 


\section{Appendix D Elasticities of Substitution}

We first derive Allen partial elasticities of substitution $\left(\sigma_{i i}\right.$ and $\left.\sigma_{i j}\right)$ from the coefficients estimated in equation (6):

$$
\begin{gathered}
\sigma_{i j}=\sigma_{j i}=1+\frac{\beta_{i j}}{s_{i} s_{j}}, \quad i \neq j \\
\sigma_{i i}=\frac{\beta_{i i}+s_{i}^{2}-s_{i}}{s_{i}^{2}}
\end{gathered}
$$

Since AES cannot be easily interpreted in the case of more than two inputs (Blackorby and Russell, 1989; Thompson and Taylor, 1995), we calculate cross- and own-price elasticities from the estimated AES, following Berndt (1991): ${ }^{29}$

$$
\begin{gathered}
\eta_{i j}=\sigma_{i j} s_{j}=\frac{\beta_{i j}+s_{i} s_{j}}{s_{i}}=\frac{\beta_{i j}}{s_{i}}+s_{j}, \quad i \neq j \\
\eta_{i i}=\sigma_{i i} s_{i}=\frac{\beta_{i i}+s_{i}^{2}-s_{i}}{s_{i}}=\frac{\beta_{i i}}{s_{i}}+s_{i}-1
\end{gathered}
$$

The cross-price elasticity measures the change in the quantity of input $x_{i}$ caused by a change of the price of input $j$ (for instance, in the case of energy and labor, $\eta_{E, P L}=\frac{\partial \ln E_{i}}{\partial \ln p_{L}}$ where $\mathrm{E}$ is energy demand) and thus has a direct economic interpretation. Substitutability/complementarity between inputs can be interpreted as follows. Based on cross-price elasticities, input $i$ is a substitute (complement) for input $j$ if $\eta_{i j}>(<) 0$. Standard errors for the estimated parameters have been reconstructed following Binswanger (1974) or Koetse et al. (2008) by using the Delta method (Greene, 2000). ${ }^{30}$

In Table D1, we detail our estimates of the elasticity of energy demand w.r.t. to changes in the price of other inputs. Substitution elasticities found in the (extensive) literature can vary both in signs and in magnitude, depending on methodological choices on the number of inputs considered as well as the input used as numeraire (Koetse et al., 2008): there seems to be no clear consensus on complementarity/substitutability. Estimates of our cross-price elasticities show that energy demand decreases in response to an increase in the price index of capital in 9/14 sectors,

\footnotetext{
${ }^{29}$ The computation of the variance of each elasticity can be found in Appendix A.

${ }^{30}$ Derivation can be found in the Appendix A.
} 
Table D1: Cross Price elasticities of substitution $\left(\eta_{E j}\right)$

\begin{tabular}{lccc}
\hline \hline & Energy & Capital & Labor \\
\cline { 2 - 4 } Food, beverages and tobacco & -0.716 & -0.004 & 0.072 \\
Textiles, textile products, leather & $(0.035)$ & $(0.033)$ & $(0.036)$ \\
Wood and products of wood and cork & -0.380 & 0.087 & -0.248 \\
& $(0.047)$ & $(0.023)$ & $(0.045)$ \\
Pulp, paper and paper prod., print. and publish. & -0.686 & -0.009 & 0.142 \\
& $(0.059)$ & $(0.025)$ & $(0.058)$ \\
Man. of coke, refined petrol. prod. and nucl. fuel & -0.511 & -0.108 & 0.145 \\
& $(0.040)$ & $(0.031)$ & $(0.044)$ \\
Chemicals & -0.229 & 0.065 & 0.024 \\
& $(0.005)$ & $(0.004)$ & $(0.003)$ \\
Rubber and plastics & -0.541 & -0.023 & 0.092 \\
Non-metallic minerals & $(0.025)$ & $(0.017)$ & $(0.017)$ \\
Metals & -0.372 & -0.079 & -0.033 \\
& $(0.051)$ & $(0.027)$ & $(0.050)$ \\
Machinery nec & -0.451 & -0.072 & 0.140 \\
Office, account.; electric., medic. and precis. engin. & $(0.024)$ & $(0.019)$ & $(0.021)$ \\
Transport equipment & -0.402 & -0.064 & -0.069 \\
Manufacturing nec; recycling & $(0.031)$ & $(0.018)$ & $(0.031)$ \\
Sale, maint. of motor vehic.; retail sale of fuel & -0.656 & 0.038 & 0.104 \\
& $(0.048)$ & $(0.031)$ & $(0.057)$ \\
Mean & -0.627 & -0.106 & 0.222 \\
& $(0.045)$ & $(0.032)$ & $(0.047)$ \\
\hline \hline
\end{tabular}

Notes: Elasticities are calculated at the mean of each cost share

and only 4/14 in the case of labor. This suggests that, on average, energy and capital are gross economic complements, while energy and labor are gross substitutes. Moreover, Table D1 shows that energy demand is more sensitive to changes in its own price than in the price of other inputs, and that the average response of energy demand to the price of labor is greater in magnitude than to the price of capital, probably because the cost share of labor exceeds the cost share of capital. 


\section{References}

Acemoglu, D. (2002) “Directed technical change," Review of Economic Studies, 69, pp. 781-809.

Acs, Z. and D. Audretsch (1989) "Patents innovative activity," Eastern Economic Journal, 15(4), pp. 373-376.

Ahmad, S. (1966) "On the theory of induced innovation," The Economic Journal, 76, pp. 344-357.

Ang, B. and F. Liu (2001) "A new energy decomposition method: perfect in decomposition and consistent in aggregation," Energy, 26, pp. 537-548.

Apostolakis, B. E. (1990) "Energy - capital substitutability/complementarity: the dichotomy," Energy Economics, 12, 1, pp. 48-58.

Arnberg, S. and T. B. Bjorner (2007) "Substitution between energy, capital and labour within industrial companies: A micro panel data analysis," Resource and Energy Economics, 29(2), pp. 122-136.

Berndt, E. R. (1991) The Practice of Econometrics: Addison-Wesley Publishing Company, Reading, Mass.

Berndt, E. R. and D. O. Wood (1975) "Technology, prices, and the derived demand for energy," The Review of Economics and Statistics, 57, 3, pp. 259-268.

Binswanger, H. P. (1974) "A cost function approach to the measurement of elasticities of factor demand and elasticities of substitution," American Journal of Agricultural Economics, 56, 2, pp. 377-386.

Blackorby, C. and R. Russell (1989) "Will the real elasticity of substitution please stand up? (A comparison of the Allen/Uzawa and Morishima elasticities)," The American Economic Review, 79,4 , pp. 882-888.

Christensen, L., D. W. Jorgenson, and J. Lawrence (1973) “Transcendental logarithmic production frontiers," The Review of Economics and Statistics, 55, pp. $28-45$.

Comanor, W. and F. Scherer (1969) "Patent statistics as a measure of technical change," Journal of Political Economy, 77(3), pp. 392-398.

Dechezlepretre, A., M. Glachant, I. Hascic, N. Johnstone, and Y. Meniere (2011) "Invention and transfer of climate change-mitigation technologies: A global analysis," Review of Environmental Economics and Policy, 5, pp. 109-130.

Dernis, H. and M. Khan (2004) "Triadic patent families methodology,"Technical report, OECD Science, Technology and Industry Working Papers.

Fisher-Vanden, K., G. H. Jefferson, H. Liu, and Q. Tao (2004) "What is driving china's decline in energy intensity?" Resource and Energy Economics, 26, pp. 77-97. 
Fisher-Vanden, K., D. Popp, and I. Sue Wing (2014) "Introduction to the special issue on climate adaptation: Improving the connection between empirical research and integrated assessment models," Energy Economics, 46, pp. 495 - 499.

Greene, W. (2000) Econometric Analysis: Upper Saddle River, NJ: Prentice Hall.

Griliches, Z. (1990) "Patent statistics as economic indicators: A survey," Journal of Economic Literature, 28(4), pp. 1661-1707.

Hagedoorn, J. and M. Cloodt (2003) "Measuring innovative performance: Is there an advantage in using multiple indicators?" Research Policy, 32, pp. 1365-1379.

Haller, S. and M. Hyland (2014) "Capital-energy substitution: Evidence from a panel of irish manufacturing firms," Energy Economics, 45, pp. 501-510.

Hesse, D. M. and H. Tarkka (1986) "The demand for capital, labor and energy in european manufacturing industry before and after the oil price shocks," The Scandinavian Journal of Economics, 88,3 , pp. 529-546.

Hicks, J. R. (1932) The Theory of Wages: London: Macmillan.

Hunt, L. C. (1986) "Energy and capital: substitutes or complements? A note on the importance of testing for non-neutral technical progress," Applied Economics, 18, 7, pp. 729-735.

IEA (2012) “Energy technology perspectives," International Energy Agency, Paris.

Jaffe, A. B., M. Trajtenberg, and R. Henderson (1993) “Geographic localization of knowledge spillovers as evidenced by patent citations," The Quarterly Journal of Economics, 108, pp. 577598.

Jaffe, A. B. and K. Palmer (1997) "Environmental regulation and innovation: A panel data study," The Review of Economics and Statistics, pp. 610-619.

Johnstone, N., I. Hascic, and D. Popp (2010) "Renewable energy policies and technological innovation: Evidence based on patent counts," Environmental and Resource Economics, 45, pp. 133-155.

Jorgenson, D. W. and B. Fraumeni (1981) Modeling and Measuring Natural Resource Substitution, Chap. Relative Prices and Technical Change, pp. 17 - 47: MIT Press: Cambridge.

Kim, J. and E. Heo (2013) "Asymmetric substitutability between energy and capital: Evidence from the manufacturing sectors in 10 OECD countries," Energy Economics, 40, pp. 81-89.

Koetse, M. J., H. L. F. de Groot, and R. Florax (2008) "Capital-energy substitution and shifts in factor demand: A meta-analysis," Energy Economics, 30, 5, pp. 2236-2251.

Lybbert, T. J. and N. J. Zolas (2014) "Getting patents and economic data to speak to each other: An 'algorithmic links with probabilities' approach for joint analyses of patenting and economic activity," Research Policy, 43, 3, pp. 530-542.

Ma, H., L. Oxley, J. Gibson, and B. Kim (2008) “China's energy economy: Technical change, factor demand and interfactor/interfuel substitution," Energy Economics, 30, 5, pp. 2167-2183. 
Martinez, C. (2010) "Insight into different types of patent families,"Technical report, STI Working Paper 2010/2.

Mulder, P., H. L. F. de Groot, and B. Pfeiffer (2014) “Dynamics and determinants of energy intensity in the service sector: A cross-country analysis, 1980-2005," Ecological Economics, 100, pp. 1-15.

Mulder, P. and H. L. de Groot (2012) "Structural change and convergence of energy intensity across oecd countries, 1970 - 2005," Energy Economics, 34, 6, pp. 1910-1921.

Nesta, L., F. Vona, and F. Nicolli (2014) "Environmental policies, competition and innovation in renewable energy," Journal of Environmental Economics and Management, 67, pp. 396-411.

Newell, R. G., A. B. Jaffe, and R. N. Stavins (1999) “The induced innovation hypothesis and energysaving technological change," The Quarterly Journal of Economics, 114, 3, pp. 941-975.

OECD ed. (2009) OECD Patent Statistics Manual: OECD.

O'Mahony, M. and M. P. Timmer (2009) “Output, input and productivity measures at the industry level: The EU KLEMS database," The Economic Journal, 119, 538, pp. 374-403.

Pizer, W. and D. Popp (2008) “Endogenizing technological change: Matching empirical evidence to modeling needs," Energy Economics, 30, pp. 2754-2770.

Popp, D. (2001) "The effect of new technology on energy consumption," Resource and Energy Economics, 23, 3, pp. 215-239. $160-180$.

(2002) "Induced innovation and energy prices," The American Economic Review, 92, 1, pp.

(2005) "Lessons from patents: Using patents to measure technological change in environmental models," Ecological Economics, 54, pp. 209-226.

Porter, M. and C. Van der Linde (1995) "Toward a new conception of the environmentcompetitiveness relationship," Journal of Economic Perspectives, 9, pp. 97 - 118.

Shephard, R. (1953) Cost and production functions: Princeton University Press.

Steinbuks, J. and K. Neuhoff (2014) "Assessing energy price induced improvements in efficiency of capital in OECD manufacturing industries," Journal of Environmental Economics and Management, 68, pp. 340-356.

Sue Wing, I. (2008) "Explaining the declining energy intensity of the u.s. economy," Resource and Energy Economics, 30, pp. 21-49.

Thompson, H. (2006) “The applied theory of energy substitution in production," Energy Economics, 28,4 , pp. 410-425.

Thompson, P. and T. G. Taylor (1995) "The capital-energy substitutability debate: A new look," The Review of Economics and Statistics, 77, 3, pp. 565-569. 
Verdolini, E. and M. Galeotti (2011) "At home and abroad: An empirical analysis of innovation and diffusion in energy technologies," Journal of Environmental Economics and Management, 61, pp. $119-134$.

Voigt, S., E. De Cian, M. Schymura, and E. Verdolini (2014) “Energy intensity developments in 40 major economies: Structural change or technology improvement?" Energy Economics, 41, pp. $47-62$.

Welsch, H. and C. Ochsen (2005) "The determinants of aggregate energy use in west germany: factor substitution, technological change, and trade," Energy Economics, 27, pp. 93-111. 